\title{
The transformation to a circular economy: framing an evolutionary view
}

\author{
Armaghan Chizaryfard ${ }^{1,2}$ (D) Paolo Trucco $^{1} \cdot$ Cali Nuur $^{2}$
}

Accepted: 16 October 2020 / Published online: 30 October 2020

(C) The Author(s) 2020

\begin{abstract}
The notion of the circular economy (CE) has recently been put forth as a strategy to mitigate climate change. It has gained attention in policy circles and in the engineering and natural science literature. In contrast to the linear model of production, use and disposal, the point of departure for the CE is the creation and sustention of a regenerative system with the goal of minimising resource inputs and emissions. However, although the emerging literature has discussed the ongoing transition process towards the $\mathrm{CE}$, mainly from an ecological perspective, the underlying mechanisms of industrial change including structural tensions have not been discussed. Responding to this gap in the literature, the aim of this paper is to discuss CE as an evolutionary process and to propose a conceptual framework that builds on a development block approach.
\end{abstract}

Keywords Circular economy · Industrial transformation · Evolutionary economics · Structural tensions $\cdot$ Development block $\cdot$ Complementarities

JEL classification Q57 · B15

\section{Introduction}

In recent decades, there has been an acceptance that industrial and technological transformation processes have evolutionary aspects. Following the seminal work of

Armaghan Chizaryfard

armaghan.chizaryfard@polimi.it

Paolo Trucco

paolo.trucco@polimi.it

1 Department of Management, Economics and Industrial Engineering, Politecnico di Milano, Piazza Leonardo da Vinci 32, 20133 Milan, Italy

2 Department of Industrial Economics and Management, KTH Royal Institute of Technology, Lindstedtsvägen 30, SE-114 28 Stockholm, Sweden 
Nelson and Winter $(1973,1982)$, with philosophical foundations dating back decades e.g. Marshall (1920), Schumpeter (1943/2000), Penrose (1959), Williamson (1966, 1970), Preston (1975), Klein (1984) and Freeman $(1974,1994)$ - the view that industrial development is an evolutionary process has permeated into other research fields. For instance, in the field of ecological economics and industrial ecology, where sustainability is a key point of departure, there have been attempts to adopt the core tenets of evolutionary economics to analyse global environmental systems (e.g. Norgaard 1981; Boulding 1992; Ring 1997).

Today, an evolutionary view of the mechanisms of industrial transformations is of the utmost importance in the context of climate change mitigation strategies. Indeed, there is a political, industrial and academic consensus that the prevailing linear economic model, which has long dominated industrial systems, has not paid enough attention to the natural environment and is therefore unsustainable (Gregson et al. 2015; Sauvé et al. 2016; Schot and Kanger 2018). In this context, the circular economy (CE) has become an important strategic framework to induce a transition towards sustainable production and consumption (Korhonen et al. 2018a).

The debate on CE currently engages scholars in the engineering and natural sciences, particularly within the field of industrial ecology (see, e.g., Morseletto 2020; Murray et al. 2017). Although there is currently no universally accepted definition and the literature on its implementation is still emerging, there is a general agreement on the paradigmatic nature of the CE (Kalmykova et al. 2018; Kirchherr et al. 2017; Winans et al. 2017). Conceptually, the CE has been described as a "multidisciplinary concept" (Sauvé et al. 2016), a "trending notion" (Ghisellini et al. 2016) and an "essentially contested concept" (Korhonen et al. 2018b). The CE has also been discussed as a strategy to meet sustainable development goals as it envisages a socioindustrial transformation towards energy and material closed-loop systems and results in systemic changes that may give rise to the evolution of institutions, industries and technologies (Millar et al. 2019; Valkokari and Antikainen 2016; WEF, Ellen MacArthur Foundation,, and McKinsey, and Company 2014). Korhonen et al. (2018b) define the $\mathrm{CE}$ as an economic system that is based on business models which replace the "end-of-life" concept with reducing - or alternatively reusing, recycling and recovering - materials in production/distribution and consumption processes.

The CE might also be viewed as a transitional evolutionary approach, and a broad range of theoretical frameworks can be used to analyse the dynamics of transitions through evolutionary approaches; sustainability transitions literature, for example, focuses on the transition towards a sustainable economic-industrial system. These frameworks include transition management (e.g. Rotmans and Loorbach 2009; Smith et al. 2005), strategic niche management (e.g. Kemp et al. 1998), the multi-level perspective on socio-technical transitions (MLP) (e.g. Geels 2002, 2010) and technological innovation systems (TIS) (e.g. Bergek et al. 2008, 2015). These frameworks have common theoretical antecedents, with slight differences in their core focuses. For instance, the MLP is influenced by evolutionary economics, innovation theory and complex system theory, explaining socio-technical transitions via the interplay of dynamics at three levels of niches, regimes and landscapes (Geels 2011; Markard et al. 2012). However, although relevant and useful, the MLP is not easy to operationalise in the context of CE because transitions towards the CE are characterised by interactions and dependencies involving multiple sectors (e.g. Prosman et al. 2017) 
which cut across several regimes and niches. As regime and niche levels often come together and are generally difficult to differentiate from each other (Berggren et al. 2015; Karakaya et al. 2018), it may be argued that the MLP does not provide the necessary analytical tools to study CE transitions in depth. The other commonly applied framework is TIS (e.g. Truffer et al. 2008), which focuses on the interconnection between technological transitions (generation, diffusion and utilisation) and the systemic changes at institutional and organisational levels. However, industrial transformations - such as the current transition to the $\mathrm{CE}$ - are not merely about a specific technology but also include broader-level transformations that involve a multitude of technologies and sectors.

Against this background, the aim of this paper is twofold. Firstly, it attempts to place the envisaged $\mathrm{CE}$ transformation within the context of the evolutionary mechanisms that underlie industrial transformations. It argues that the current CE discourse, which is mainly based on an ecological view, needs to be complemented with an evolutionary view of industrial transformation. Secondly, it revisits the development block (DB) concept (Dahmén 1984, 1988), which refers to positive and negative transformative pressures during times of structural change. Introduced by Dahmén (1988, p. 5) and defined as "a sequence of complementarities which by way of a series of structural tensions, i.e. disequilibria, may result in a balanced situation", the DB goes beyond the dichotomies of regime and niche (of the MLP) and the technology-based operationality of TIS. Thus, we propose that the development block (DB) analytical model can be a relevant framework to analyse industrial transformations towards the $\mathrm{CE}$ paradigm. The $\mathrm{DB}$ framework is useful for two main reasons. Firstly, since the CE is an evolving system, the DB notion allows for the identification of cross-sectorial interdependencies during transformation processes which does not follow conventional industrial classification and cannot be taken as a point of departure for the MLP and TIS frameworks. Secondly, the two key notions of structural tensions and complementarities, which form the foundations of DB, show that evolutionary patterns of transformation at system level might not necessarily lead to sustainable economic development.

The ambition of this paper is not to provide a solution to all the limitations and challenges of industrial transformation towards the CE. Rather, we attempt to offer a comprehensive understanding of the nature of the $\mathrm{CE}$ as a complex evolutionary system. Along this line, the paper contributes to the fast-growing $\mathrm{CE}$ field of research by expanding the boundary of application of DB theory to include CE. Previous studies on DB have mainly discussed ex-post events, i.e. historical industrial change. However, in our study, we show the applicability of DB in the ongoing transition process towards the $\mathrm{CE}$, which is an ex-ante situation. Further, the prominent contribution of this paper is to align the ecological and economic evolutionary patterns of transformation to the CE.

In addition to this introduction, the paper consists of six sections. In the next section, we provide an overview of the $\mathrm{CE}$ from economic and ecological evolutionary perspectives by discussing the relevant literature. In section 3, the DB analytical model is introduced with further discussion on its suitability for understanding evolutionary aspects of transformation towards the CE. In addition, we illustrate the evolutionary principles of ecology in relation to the $\mathrm{CE}$, with the goal of proposing a novel framework for the transformation process towards the CE from an evolutionary perspective. In section 5, the paper shifts to explaining in detail all the dimensions 
and elements of the proposed framework. Finally, in section 6, we conclude by highlighting the main contributions of the study and avenues for further research.

\section{Circular economy}

Although the undercurrents of $\mathrm{CE}$ date back more than half the century (see e.g. Boulding 1966a), the concept has gained potency due to the urgency of mitigating climate change (Korhonen et al. 2018b). Currently, it is mainly driven by policymakers, such as the EU, business development bodies, such as the Ellen MacArthur Foundation (Ellen MacArthur Foundation 2016; WEF et al. 2014), and individual countries, such as China ( $\mathrm{Su}$ et al. 2013) or Sweden (Milios and Matsumoto 2019), who have incorporated it in their industrial policy. However, there is still no consensus on how to define the CE, and several definitions exist (Morseletto 2020). For instance, Jiao and Boons (2014) define it as "a holistic concept covering the activities of 'reduce, reuse, and recycle' in the process of production, circulation, and consumption". Kirchherr et al. (2017, p. 224) analyse 114 definitions of CE and conclude that the CE is "an economic system that is based on business models which replace the 'end-of-life' concept with reducing, alternatively reusing, recycling and recovering materials in production/distribution and consumption processes".

The principles of the CE emphasise closed-loop material flows, by considering product reuse, remanufacturing, reprocessing and recycling. These are largely categorised using various frameworks such as the 3 Rs (reduction, reuse and recycling) (Blomsma and Brennan 2017; King et al. 2006), which in turn has influenced national policies such as China's 2009 Circular Economy Promotion Law of the People's Republic of China or Japan's 2000 Fundamental Law for Establishing a Sound Material-Cycle Society (Sakai et al. 2011). Other frameworks include the 4Rs (based on the European Union's Waste Framework Directive, EU Directive 2008/98/EC), the 6Rs (reuse, recycle, redesign, remanufacture, reduce, recover) (Sihvonen and Ritola 2015) and even the 9Rs (Kirchherr et al. 2017; Potting et al. 2017; van Buren et al. 2016). The 9Rs principles are categorised within three groups of strategies for transitioning from a linear to a circular economy: smarter product use and manufacture, extend use-cycle of products and their parts, and useful application of materials. The study by Saidani et al. (2019) provide an extensive review on existing measurement tools to support implementation of CE principles and propose 55 circularity indicators at the micro, meso and macro system levels.

Some scholars (Geissdoerfer et al. 2017; Korhonen et al. 2018a; Martins 2018; Murray et al. 2017) address the theoretical foundations of CE in relation to its core principles. Interestingly, the most referenced theories include the "spaceman economy" and the "cowboy economy" by evolutionary economist Boulding (1966b), the "fourth law"/“entropy law" by Georgescu-Roegen (GR) (1971), the "limits to growth" thesis of the Club of Rome in the 1970s by Meadows et al. (1972), "Only one earth" by pioneering economist Ward and Dubos (1983), and last but not least the "steady-state economy" by eco-economist Herman Daly (1996). The common arguments in these seminal works were crafted to respond to the limited stores of natural resources and the capacity of the ecological system to absorb the negative environmental impacts of linear economic development. In this regard, scholars in the research field of ecological 
economics have positioned the $\mathrm{CE}$ as the antithesis of neoclassical economics (Temesgen et al. 2019) and relate it to notions such as bio-economy and green economy. (see, e.g., D’Amato et al. 2019; Giampietro 2019).

In the engineering field, the $\mathrm{CE}$ literature builds to a large extent on industrial ecology principles and models. For several decades, industrial ecologists and industrialists (e.g. Simmonds 1862; Fischer-Kowalski and Haberl 1998; Parkins 1930; Graedel and Allenby 1995; Allenby 1998) have pointed to the systemic nature of industrial metabolism, and to the idea that "waste is food" for industrial processes. Similarly, the CE literature adopts a systemic approach towards the lifecycle of materials and products, starting with material extraction, processing, use and disposal. Indeed, some studies assert that CE principles are framed based on the theoretical support and guidance of laws of ecology (Commoner 1971), regenerative design (Lyle 1994), a product lifecycle perspective, performance economy (Stahel and Reday 1976; Stahel 1982; Stahel 2010) and contemporary concepts such as cradle-to-cradle (McDonough and Braungart 2002).

\subsection{The evolutionary nature of the CE}

Generally, industrial transformations - such as the envisaged transformation towards the $\mathrm{CE}$ - are about understanding the logic and mechanisms of radical systemic changes. Assuming that the $\mathrm{CE}$ is a transformative mechanism, it is impossible to talk about the dynamic and evolving aspects of change without taking a system perspective. As Dosi and Nelson argue (Dosi and Nelson 1993, p. 154), the evolutionary term is used to explain the characteristics of "the movement of something over time, or to explain why that something is what it is at a moment in time in terms of how it got there; that is, the analysis is expressly dynamic. Second, the explanation involves both random elements which generate or renew some variation in the variables in question, and mechanisms that systematically winnow on extant variation".

The CE as an evolving system consists of several levels, scopes and entities. In the literature, the $\mathrm{CE}$ is mainly investigated and discussed according to three scopes of analysis: macro level (see, e.g., Jiao and Boons 2014; McDowall et al. 2017; Sakai et al. 2011; Winans et al. 2017; Yong 2007), which analyses how the CE influences industrial structure at national and global levels; micro level (see, e.g., Chen et al. 2020; Moreau et al. 2017; Park et al. 2010), where studies focus on products, firms, and consumers and their preferences (Ghisellini et al. 2015; Sauvé et al. 2016; Bundgaard and Huulgaard 2019; Kuokkanen and Sun 2019); and the in-between meso level (see, e.g.,Li 2011; Pan et al. 2014; Govindan and Hasanagic 2018; Baldassarre et al. 2019; Frei et al. 2020), which is related to local policies and actions, such as those promoting industrial parks and industrial symbiosis. Irrespective of the level of analysis, responses to radical changes can be viewed from several stances, including the institutional level, industrial structure, organisational strategies, and societal values and norms.

\subsubsection{Institutional level}

Policy bodies and the decisions they make are vital components of the CE system, since they shape the national and international standards that aim at reconfiguring the whole industrial structure (Yong 2007; Sakai et al. 2011; Jiao and Boons 2014; McDowall 
et al. 2017; Winans et al. 2017). Hence, the industrial system could also encompass radical and systemic innovation as the main driver for reaching $\mathrm{CE}$ principles and ambitions (Zheng and Chen 2011; Valkokari and Antikainen 2016; Linder and Williander 2017; de Jesus and Mendonça 2018; Kinnunen and Kaksonen 2019). In such a system, there is constant incentive and stimulation from both market and legislative forces to search for innovative and creative solutions, such as cleaner technologies, business models and institutional capacity (de Abreu and Ceglia 2018; Ranta et al. 2018), as well as environmentally oriented policy instruments (de Aguiar et al. 2017; Ferronato et al. 2018; Geissdoerfer et al. 2017; Milios 2017). However, the dominant institutional system and privileged policy prescriptions have been established for the linear industrial-economic system. Thus, new standards and regulations might be the outcome of path dependency in institutional rules, which makes it difficult to implement radical changes (Campbell-Johnston et al. 2019; García-Quevedo et al. 2020). For instance, non-conducive legal systems and misaligned incentives can create negative mechanisms that hinder the transformation to the CE (Pajunen et al. 2013; Carly A. Fletcher et al. 2018). A case study by Su et al. (2013) looked at national strategies in China, concluding that weak economic incentives, poor enforcement ability of legislation and limitations of the existing government's management system are some of the institutional challenges faced by CE implementation in China. A similar study by Ilić and Nikolić (2016) examined the waste management system in Ljubljana Municipality, Serbia, where they noted the need for a sustainable financial model, the availability of governmental funds and changing tariffs in municipalities. The institutional challenges are not only limited to national boundaries. For instance the implementation of closed-loop material system in economies is influenced by both global and domestic CE policy objectives (Geerken et al. 2019). Similarly, the study by Bukhari et al. (2018) shows the interdependency of implementation of the national programme for textile and clothing recovery in France and international bans on importing used textiles in the African market. Moreover, the institutional adaptation to the CE may develop at different timeframe, meaning that some countries are early adopters and others are followers. Marcela and Morales (2020) argue that the transition path created by European countries is followed by nations in Latin America without revisiting the path and its suitability to their cultural and political context.

\subsubsection{Industrial and organisational structures}

Industrial transformation creates radical changes in dominant industrial structures and economic relationships. Hence, a resistance to new structures may be encountered in industrial relations and inter-organisational relationships (e.g. supply chains). Since the appearance of new entities and relationships requires fundamental changes in the industrial structure that encourage businesses which traditionally work as separate units to become engaged in complex exchanges of resources such as material, water, energy and by-products (Mathews and Tan 2011; Pan et al. 2014; Ghisellini et al. 2016; Saavedra et al. 2018). The CE introduces a closed-loop value chain via the exchange of products, the adoption of cleaner production technologies and higher interdependencies among the actors (see, e.g., Baldassarre et al. 2019; Ciulli et al. 2019). Consequently, during this evolutionary process, some parts of the system become obsolete, such as technologies, infrastructure or former industrial relationships. An example is green 
supply chain and closed-loop supply chain practices, that introduce new configurations as well as relationships among the main actors, ranging from suppliers, manufacturers, transporters, warehouses and retailers to customers, remanufacturers, recyclers and retailers of the second market (Genovese et al. 2017; Lieder and Rashid 2016; Masi et al. 2017; Nasir et al. 2017; Patala et al. 2020; Witjes and Lozano 2016; Zeng et al. 2017). The study carried out by de Abreu and Ceglia (2018) shows the link between relationships among actors and their organisational capacity within the National Industrial Symbiosis Programme (NISP) in the UK. Based on their study, co-ordinating the network is one of the main challenges in the new industrial structure, which can be overcome via the availability of information, logistics infrastructure, changes in consumer behaviour and encouraging regulations. However, as with all long-established systems, the dominant linear industrial foundations play as lock-in mechanisms for the transformation to the $\mathrm{CE}$ in various areas. For instance, at the supply chain level, the lack of an infrastructural system for reverse logistics is the main bottleneck for feeding closed-loop production systems with recovered raw materials (Govindan and Hasanagic 2018; Frei et al. 2020). Also, from a system perspective, the lack of viable product design methodologies (Andrews 2015; Moreno et al. 2016; De Los Rios and Charnley 2017) and the absence of feasible business models (Rizos et al. 2016; Stål and Corvellec 2018) are identified as the primary operational and strategic issues (Franco 2017).

The transformation towards the $\mathrm{CE}$ mandates firms to change their organisational structure, capabilities and strategies. In this regard, the $\mathrm{CE}$ literature on strategic management at firm level primarily focuses on the transformation of embedded linear dominant business models (Bocken et al. 2016; Bocken and Short 2016; Lewandowski 2016; Winans et al. 2017). Also, in recent years scholars have further analysed the role of business models to enable the transition to the CE (Hofmann 2019; Rosa et al. 2019; Centobelli et al. 2020; Chen et al. 2020). The radical change in firms' existing business models is in line with the dynamic capability of companies to adapt to new changes in the system (Teece et al. 1997). The study by Khan et al. (2020) explores the dynamic capability of incumbents identifying the business opportunities enabled by CE principles. However, the high risk of changing an incumbent business model may create paradoxical tensions in $\mathrm{CE}$ decisions. Indeed, the principles of the $\mathrm{CE}$ influence the way firms create, deliver and capture value in their business model (Bocken et al. 2016; De Angelis and Feola 2020). This new business model requires managers and other employees to be engaged in the process of changing the organisational culture and encouraging the company to take advantage of the opportunities offered by the CE (Rizos et al. 2016; Stål and Corvellec 2018; Ünal et al. 2018). In this context, the dilemma of choice between exploring new opportunities or exploiting existing business resources and activities can be explained by an evolutionary perspective. The dilemma of choice is noticeable in the study by Whalen et al. (2018) which describes the challenges of the Swedish ICT "gap exploiter" sector in implementing the CE business activities of repairing, refurbishing and remanufacturing. The business of gap exploiters is dependent on the engagement of OEMs who have a lack of interest in changing the dominant design of their products to be suitable for re-utilisation activities. On the other hand, the high cost of reverse logistics, high taxes on labour and the lack of sufficient volumes make the business model of generating, delivering and capturing value from ICT reuse less attractive for gap exploiters. 
Another example is the connection between the transition of business models and the diffusion of green technologies and practices. Bidmon and Knab (2018) state that dominant business models are a critical barrier where resources have been deployed according to the dominant logic, and lead to path dependencies and fear of cannibalisation. It is worth noting that the research focus on the concept of circular business models is relatively recent (see, e.g., Vermunt et al. 2019; Salvador et al. 2020). However, the idea of product-service systems (PSSs) (Mont 2002; Tukker 2004; Tukker and Tischner 2006) as a resource-efficient way of creating value propositions has gained significant attention from scholars in recent decades. Tukker's (2015) review study showed that PSSs have the potential to contribute to achieving resource efficiency in the CE. Other studies suggest that PSSs and CE based business models can be complementarities (Kjaer et al. 2019); integration of PSSs at manufacturing sectors can enables closed-loop supply chain of materials and products (Kühl et al. 2019). Further, the case study by Sousa-Zomer et al. (2018) has followed Witjes and Lozano's (2016) study, arguing that the shift towards PSSs might provide a basis for companies to move to circular business models. Similarly, the study by Linder and Williander (2017) looked at the business model of small bicycle firms adding leasing options to guarantee the return flow of their products by exploring the product-service offering model. However, this study indicated that this radical change often involves practical challenges and is perceived by firms as a source of financial risk. In the rental and performance selling business model, the product ownership stays with manufacturers and in the supply chain which hinders a short sell-and-buy process. Tukker (2015) has pointed to another evolutionary aspect of the residual value within reusing the product, arguing that lease and rental systems are not appropriate for products that retain little value after usage. Moreover, the study by Rizos et al. (2016) identified eight potential barriers for small and medium-sized enterprises to adapt to the CE principles: company environmental culture, a lack of capital, a lack of government support/ effective legislation, a lack of information, administrative burden, a lack of technical and technological know-how, and a lack of support from the supply and demand network.

\subsubsection{Societal norms and behaviours}

Market forces do not merely control the transition process; throughout history, the normative and behavioural aspects of society have always been a game changer. Transition studies have discussed the concept of cultural lock-in, explaining that social behaviour is embedded in the dominant consumption system. Societal actors are the profoundly relevant components of the CE system; their values and preferences have a direct and indirect influence on the degree to which $\mathrm{CE}$ goals can be accomplished on a system level (Guo et al. 2017). Thus, it can be argued that understanding societal expectations and changes is at the heart of the transition towards the CE (Stahel 2010; Ghisellini et al. 2016; Milios 2017). Social awareness is growing rapidly and is becoming a critical parameter affecting consumers' purchasing decisions (Elzinga et al. 2020). The key role of consumers in the development of markets is also studied by Van Weelden et al. (2016). In their work, they identify the barriers that prevent customers from buying refurbished mobile phones: a lack of awareness, understanding the concept, availability and the thrill of newness. The concept of 
circular design is one of the proposed solutions in changing consumer behaviour (Daae et al. 2019). Real examples of companies such as Patagonia Worn Wear shows customers feel they have complete control when choosing refurbished worn Patagonia garments. Korhonen et al. (2018b) also highlight the importance of societal actors' decisions as influenced by cultural factors on the flow of secondary material. They highlight that the definition of material flow is temporal, spatial and cultural. Thus, the CE should be placed in and considered within the temporal, spatial and cultural contexts. Additionally, the role of governments in growing social awareness and a radical mind shift on sustainable consumption needs more in-depth impact analysis, since the evolution of consumers' behaviour can be seen as an outcome of the dominant legal framework. In this regard, Dalhammar (2019) proposes a hierarchy of consumption behaviours in the CE to help the development of European Union law. He looks at various roles played by consumers in Europe, the effect of Directive $1999 / 44 / \mathrm{EC}$ on certain aspects of the sale of consumer goods and associated guarantees, and the Swedish laws which allow consumers to make tax deductions for certain repairs. Likewise, the study by Bocken et al. (2017a) addresses the importance of policy strategies, such as consumption reduction and waste prevention, to achieve long-term $\mathrm{CE}$ goals.

\section{Development block}

As indicated earlier, the development block (DB) framework of industrial change was developed by the Swedish evolutionary economist Eric Dahmén (1950). DB introduces a set of concepts that connect evolutionary economic theory with industrial and technical change analysis. The theoretical foundation of DB is Schumpeterian dynamics. It is closely related to business cycle theory (Keynes 1937), and centres on the transformation of industries, companies and technologies. DB also has similarities to the concepts of salient, reverse salient and critical problems (Hughes 1992,Hughes 1983). DB analyses industrial transformations and the causal mechanisms behind them by capturing the evolution of essential aspects of an industrial system which is not necessarily related to or peculiar to a certain industry or technology (Carlsson 1997). In suggesting the DB framework, Dahmén (1984) used a Schumperterian approach and discussed industrial transformation as a series of introductions of forces - such as new technologies, regulations, actors, products, market and services - to the prevailing system. Transformation forces create imbalances, which result in tensions and uneven development within and between industries (Dahmén 1984). As a result, disturbances occur within existing structures and old parts of the system. Accordingly, the dual character of the transformation process can be viewed as a historical process of sequential movements between the two extreme situations of possibility and necessity, where transformations affect more than one industrial sector containing transformative pressure (Dahmén 1988). This pressure is labelled as positive when there are possibilities for economic and industrial development. Negative transformative pressure, on the other hand, exists when there are strong requirements to adjust and adapt. Dahmén (1988, p. 5) defines DB as "a sequence of complementarities which by way of a series of structural tensions, i.e. disequilibria, may result in a balanced situation". 


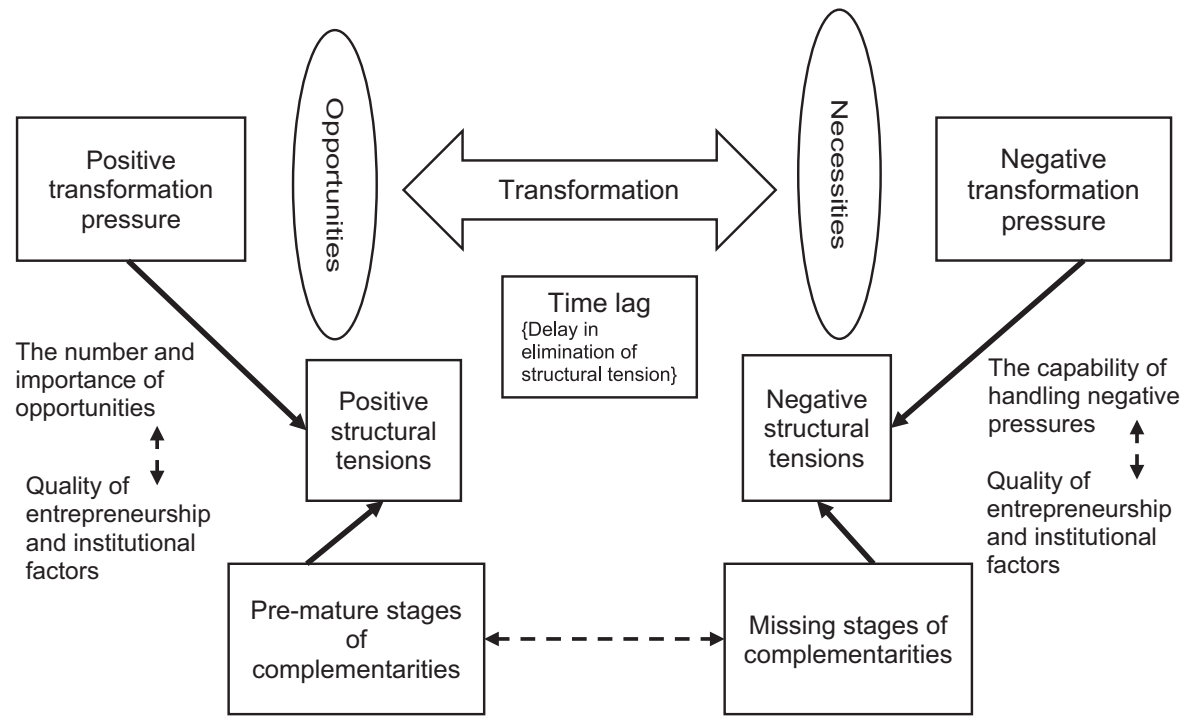

Fig. 1 The components of the development block analytical model and their main relationships

\subsection{The components of DB}

As shown in Fig. 1 below, DB consists of conceptual elements with several components to investigate the industrial transformation. These include complementarities, transformation pressure, structural tension and entrepreneurship activities, as well as institutional dynamics. Complementarities are dependencies among interrelated actors in a development block. The actors include companies, institutions, industries, entrepreneurs and other organisations which are complementary in the development of an economic/industrial system (Novotny and Laestadius 2014). The coherent development of complementarities in development blocks could be required for the transformation process (Dahmén 1988). The lack of balance between the development of complementarities, i.e. pre-mature stages and missing-complementary stages, as well as the joint effects of inner and outer transformation pressures, create tensions (positive and negative) within the industrial system. Nuvolari (2019) defines complementarities as clusters of technologies linked together that mutually stimulate each other. The case example is ICT evolution in which the DB could be structured around the co-evolution of semiconductor-computer-software-networking equipment. Novotny and Laestadius (2014) present Dahmén's examples of transformation pressures as “(a) appearance of new markets; (b) exploitation of new raw materials and energy; (c) disappearance of old products/services (old markets); and (d) closure of old sources of raw materials and energy". As a result, tensions can arise between available resources and the capabilities required to take advantage of new business opportunities (Carlsson 1997). Thus, the imbalance stage of the system is driven by transformation pressures and discontinuities in the development pace of different complementarities.

Structural tensions can be repeated over time in different settings and analysed on different levels. One approach is to analyse tensions at a company, industry, or institutional level. Another approach analyses tensions at technical, organisational 
and societal levels. Different industries might not develop at the same pace; some industries are pioneers while others lag far behind (Erixon 2011). Dahmén (1988) emphasises the fact that factors such as institutional condition (e.g. government regulation) might cause a delay in achieving a balance and eliminating structural tensions. He labelled these factors as the quality of entrepreneurial activities and institutional factors (Dahmén 1988). Figure 1 shows the conceptual elements in the DB as well as their relationships.

Scholars that apply the DB analytical model generally focus on specific periods or places of the industrial development process to identify the driving forces of the transformation. For example, Novotny and Laestadius (2014) show structural tensions created by product and process innovations that can be interrelated and complementary to form a new development block in the wood-based biomass industries. Similarly, Enflo et al. (2008) identify two main development blocks in the electricity generating sector in Sweden by proposing a quantitative approach. The case study by Haley (2018) focuses on TIS and the structural tensions created by the diffusion of technologies. He argues that the elimination of structural tensions created by the diffusion of renewable energy requires the complementarity technologies to come along and fill the technical gaps. By the same token, Andersen and Markard (2020) put emphasis on the suitability of DB and the concept of transition tension to unfold the interdependency of multitechnologies during transition process.

The DB as an analytical model can facilitate identifying and explaining the pathways of industrial transformation from an evolutionary perspective in the context of the CE. Indeed, the $\mathrm{CE}$ as an evolving system can be viewed as a dynamic structural tension that initiates transformation pressures within the prevailing industrial system. Thus, the concepts of DB could help to distinguish different mechanisms of the transformation process, the most relevant and powerful DBs within the system, and the role of positive and negative transformative pressures on structural tensions. Moreover, the DB conceptual model enables a clarification of the level of different tensions and the interactions of different complementarities within the socio-technical system. In DB, political and other institutional factors are key driving forces during transformation processes. By focusing on different institutional circumstances, we can see that the transformation to the $\mathrm{CE}$ is coupled with different structural tensions in different political and institutional contexts.

The implementation and formation of CE principles in China and Europe can serve as an example of how different institutional settings (e.g. different environmental policy priorities and sustainable development agendas) result in different schemes for transformation to the CE. China's CE perspective was developed around issues of pollution and in the context of China's rapid economic growth; in contrast, the European Union focuses more on business opportunities along with resource efficiency implications. Thus, the Chinese government created transformation pressure by adopting a top-down approach and passing a different set of incentives and penalties at national, regional and industrial cluster levels. By contrast, European nations emphasised a bottom-up approach, elaborating on the competitiveness of European industries, innovative technical and business solutions for environmental challenges such as climate change, and, most importantly, social awareness of consumerism phenomena. Thus, in a European institutional context, the structural tensions and complementarities are related to the coevolution of the CE strategies listed by Kalmykova et al. (2018). These include 
industrial incentives for using renewable energies, environmental regulations and penalties for cleaner production/technologies, material exchange industrial platforms and networks at regional, national and local levels, creating zero-waste industrial systems by incentivising transparency and a secure material database, and consumption awareness (e.g. product/process redesign with incentives for repair and product labelling requirements) (Gregson et al. 2015; Demirel and Danisman 2019).

\section{An analytical framework}

The basic principles of CE manifest itself in the interconnection between the dynamics of economic and ecological development. This connection has, particularly, been explored in depth in the CE literature from an ecological point of view, focusing on the throughput of energy and material to meet the demands of industrial-economic development (Lieder and Rashid 2016; Prosman et al. 2017; Kalmykova et al. 2018; Reike et al. 2018a). The CE emphasises the importance of closing technical and biological loops in a cyclical system of material and energy flows rather than linear flows. Ring's (1997) terminology of evolutionary strategy captures the evolutionary pattern of economic and ecological development. As presented in Fig. 2, the evolutionary pattern relies on the flows of basic elements such as energy, material, information, space and time. Similarly, Boulding (1981, 1992), one of the earliest contributors to evolutionary economics and one that is often cited in the CE debate, also noted the importance of these elements. Valentinov (2015) addresses the same basic elements that need to be taken into consideration when explaining evolutionary processes in the field of economic development: time, energy, human know-how and material. Thus, the evolutionary process can be analysed by measuring the changes in the flows of the mentioned elements in both the socio-economic and ecological systems. It can be argued that the CE may be seen as an evolutionary strategy, which involves the flow of the same basic elements. This is because it is deeply rooted in the notions of closing the flow of material, reducing the need for virgin raw material and keeping material inside the loop. At the same time, the CE envisions energy-efficient industrial systems and the generation of renewable energies, and above all the regeneration and extension of economic value through innovative business models. Time and space are key dimensions to unlock the evolutionary pattern of environmental and economic development. The environmental and social impacts of economic actions become visible throughout the time and often in unexpected geographical spaces. Time illustrates the gradual increase in complexity of the system and the need for conservation of the resources and ecological restoration. In summary, CE addresses how to sustain the complex evolving environmental and economic systems, which are inherently interconnected.

Therefore, based on the discussions in the previous sections, we present here an evolutionary framework of transformation processes in the CE context. The framework is the integration of evolutionary aspects of transformation to the $\mathrm{CE}$ from economic and ecological perspectives. The framework consists of two main parts:

- The three-dimensional space of the evolutionary transformation to the CE;

- The evolutionary dynamics of the transformation to the CE. 


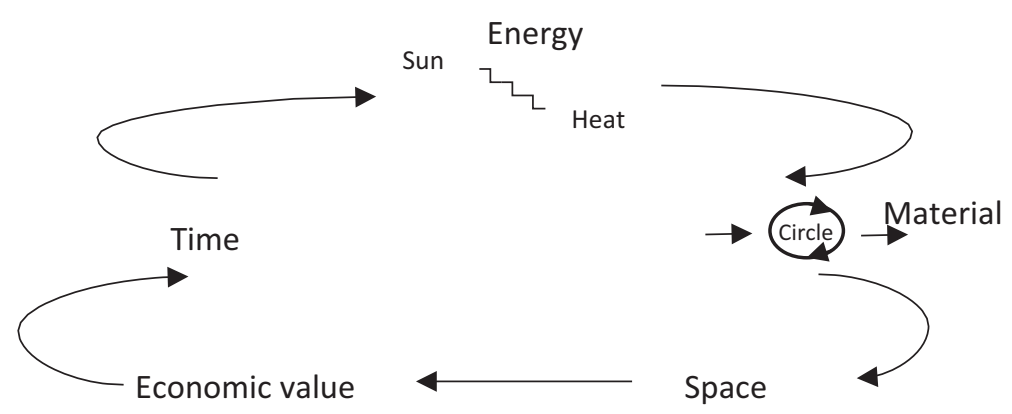

Fig. 2 Ecological and economic principles of system development, adapted from Ring (1997)

The first part is presented in Fig. 3 and shows the three dimensions, representing the ecological and economic evolutionary cornerstones of the CE. The flows of basic elements largely build on the work carried out by Boulding $(1981,1992)$ and Ring (1997), on the idea of evolutionary strategies, ecological principles, including the flow of energy and material in the ecosystem, and the fact that economic value, cultural and social aspects develop in an evolutionary pattern. The two other dimensions of the framework are generated based on DB and Dahmén's (1988) original idea of dynamics of structural tensions and complementarities during transformation processes. These two approaches make it possible to identify and analyse interdependencies and inertia at different levels of the economic system during the transformation to the $\mathrm{CE}$.

\subsection{Flows of basic elements in the CE}

The topology and intensity of flows of energy, material, economic value chains and societal values in the CE system are the key elements. They define the state of the system at different stages of the transformation process, concerning both temporal and spatial dimensions. These are the main ecological principles that explain the evolutionary patterns of development in the system, which is the foundation of the CE from an ecological perspective. The assessment of flows of essential elements can be used to

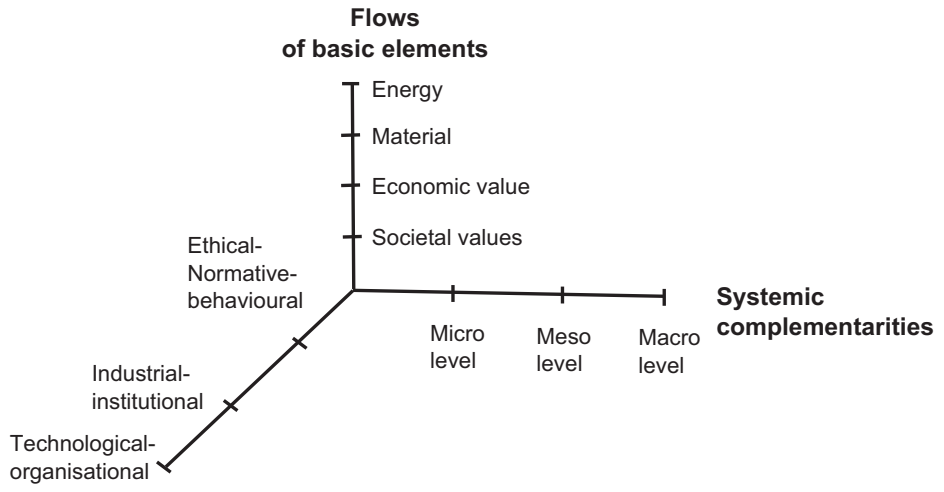

\section{Circular tensions}

Fig. 3 The three-dimensional space of evolutionary transformation to the $\mathrm{CE}$ 
show the sequences of imbalance and relatively balanced stages of the CE system, and thus to track transformations over time and space.

Energy flows The CE principles demand the efficient use of energy and the generation of renewable energy. Therefore, the circularity state of the system can be realised by showing energy flow and the availability of renewable energy sources (e.g. Bobba et al. 2018). However, this goal needs to be considered from a system perspective. In some instances, industrial activities towards the diffusion of renewable energy technologies are not always from a systemic point of view, which might end with the reverse effects of extensive use of energy in other parts of the system. One of the most relevant examples is the diffusion of solar photovoltaic systems (Corcelli et al. 2018; Domínguez and Geyer 2017; Gönen and Kaplanoğlu 2019). Solar panels contain rare earth metals, and it is recommended from economic and environmental points of view that these are recovered at the end of the panels' useful life. However, so far, this power-generation technology has been associated with energy-intensive mining activities during production and a waste management challenge after the lifecycle of the panels (Cyrs et al. 2014; Xu et al. 2018).

Material flows Similar to energy flows, closing the material loop is a big step in the transformation towards the CE (Gaustad et al. 2018; Ryen et al. 2018). Thus, this element reflects the state of material flow within the system and possible outflow areas (e.g. Reh 2013; Jackson et al. 2014). The possibility of keeping materials in the cycle of usage as long as possible is the goal of the CE; however, this idea should be implemented along with a reduction in the use of virgin materials, an increase in the use of bio-based materials and the elimination of reusing intense energy materials (Grundmann et al. 2013; Matus et al. 2012). In this regard, the circular design approach is the primary stage that promotes the production of reusable and energy-efficient materials/products (Bocken et al. 2016).

Change in economic value Transformation to the $\mathrm{CE}$ is expected to contribute to economic development via the generation of new economic values. The transformation towards closed-loop value chains should always be considered in CE transformation studies (e.g. Makov and Font Vivanco 2018; Zacho et al. 2018). One of the challenges in reusing materials and products is the price positioning, which requires different measurements of economic values. Business activities such as repairing, remanufacturing, refurbishing and recycling are value-adding processes which consume energy, time and other resources. However, this fact is not very clear to customers, who cannot relate the price of reused materials/products to the added values (Cavalcanti et al. 2018). On the other hand, the existing tools of price positioning are not easily able to give economic value to something which conventionally could not have any value in the dominant linear socio-economic system (e.g. Fletcher et al. 2018). This change in economic value results in competition between actors and the creation of innovative business models which make it possible to capture new economic values (Heyes et al. 2018; Perey et al. 2018). The creation of circular economic value is ongoing and changes over time, which is the main driver in circular economic development. 
Societal values Actors within society play a significant role in the transformation towards the CE. Thus, it is vital to understand and analyse changes in their behaviours and preferences, i.e., the phenotypes of driving circular values are key elements in industrial transformation studies on CE (e.g. Guo et al. 2017; Ferronato et al. 2018). The engagement of social actors facilitates CE principles; for instance, in the context of reverse logistics, incentivising consumers to return old products involves establishing a new cultural behaviour. On the other hand, the normative aspects of consumerist behaviour have drawn the attention of scholars to rebound effects in re-selling and the circularity of economic value, which might increase the overall amount of industrial production (Makov and Font Vivanco 2018). Thus, the complexity of cultural lock-in can challenge the environmental implications of the CE.

\subsection{System complementarities}

This dimension shows the evolutionary approach of economic and industrial change in transformation process towards the CE. This can be only understood at a system level, which indicates the co-evolution of entrepreneurs, innovators, industrialists, social actors and policymakers. Systemic complementarities show the boundary of interdependencies and interactions among entities at micro, meso or macro level. It should be noted that the concept of systemic complementarities is adapted from the Dahmén's (1988) original ideas on DB. The concept of complementarity in DB is limited to certain interdependencies at micro level during industrial transformation; however, in the context of the CE we have expanded the boundary of applications for this concept to the system level. Hence, this dimension enables us to explain the dynamics of interdependencies among different parts of the CE system during transformation processes (e.g. development of technologies, business models, infrastructures and institutional structure).

Micro level At this level, the nature of interdependencies in the transformation process are in the form of the development of a single product (e.g. Niero and Olsen 2016), production process (e.g. Lacasa et al. 2016) or an individual firm's business model (e.g. Heyes et al. 2018). Thus, essential complementarities at this level can range from new design strategies (e.g. Bocken et al. 2016; De Los Rios and Charnley 2017), innovative materials (Todeschini et al. 2017) and production technologies (Quina et al. 2018; Schalkwyk et al. 2018) to business models (Lewandowski 2016; Perey et al. 2018). These complementarities enable changes in the structure of products to be disassemblable, bio-degradable and produced energy efficiently. Thus, without those developments, new business models and the production process cannot be successfully implemented. The study by Vanegas et al. (2018) illustrates the essential requirements of the appropriate design of the disassembly process and manufacturing end-of-life products. In the same manner, organisational and institutional capacities are necessary for the development of new business models, such as financial management, administrative capabilities and the development of new partnerships and industrial collaborations (de Abreu and Ceglia 2018; Ilić and Nikolić 2016). 
Meso level The typical units of analysis at meso level are industrial changes in supply chains (e.g. Pan et al. 2014; Park et al. 2010), industrial parks/symbiosis (e.g. Prosman et al. 2017), and regional policies and industrial actions (e.g. Jiao and Boons 2017; Silva et al. 2017). Hence, different types of complementarities at this level facilitate the transformation process through the development of industrial networks, collaborations and infrastructural facilities. The $\mathrm{CE}$ requires new industrial relationships and needs a new configuration of the supply chain to close the loop of materials (Jabbour et al. 2016; Masi et al. 2017). It opens up opportunities for new forms of industrial collaborations to exchange and share resources. It depends on actors' interests and their trust in new business activities, and on the emergence of new processes and actors (e.g. Lieder and Rashid 2016). Circular business models, technologies and even new regulations cannot be successful without a systemic change in dominant industrial infrastructures, relationships, transparent data sharing and industrial platforms to connect actors.

Macro level Here, the unit of analysis explains the industrial transformation at macroeconomic level, and structural changes on a national, multinational or global scale (e.g. Jackson et al. 2014). Therefore, the complementarities investigated at this level are defined as synchronised national, regional and international legislation (e.g. Yong 2007; Gregson et al. 2015; Ranta et al. 2018). The implementation of CE principles requires support from institutions and policymakers. For instance, conflicting export and import regulations with regard to industrial/household waste, the definition of secondary material, or guidelines and standards that hinder the implementation of reverse logistics between countries. The case study carried out by Bukhari et al. (2018) explains the evolution in institutional policy in African countries that changed the market dynamics and restricted importing waste from Europe. Ambiguity in the definition of secondary materials and their economic value can delay growth in market demand and mislead the pricing mechanisms (e.g. Zink and Geyer 2017). Also, societal infrastructure (e.g. Liu et al. 2009; Atlason et al. 2017) can be discussed at macroeconomic level, demonstrating that social acceptance and awareness are the slowest evolving aspects of socio-industrial transformation.

\subsection{Circular tensions}

The notion of tensions in industrial transitions was discussed decades ago by scholars such as Joseph Schumpeter (1939) and Dahmén (1950) to capture frictions when incumbents encounter challenges related to the evolution towards a new system. As indicated earlier, for instance, Dahmén (1988) argued that transformation processes create tensions within companies, industries and institutions that are driven by transformation pressures, either positive (opportunities) or negative (necessity), to adjust or adapt, and are due to a lack of coherent development of complementarities. We argue that the sources of these tensions and the way they are detached are different in the context of the CE. We propose that tensions in the transformation towards the CE do not necessarily have negative connotations. This means that tensions can exist within technical developments, organisational innovations, industrial structures and regulatory systems that aim to achieve the CE. We call these frictions circular tensions. These can 
occur due to competition and resistance between linear and circular economies as well as unsystematic attempts towards the CE. Similarly, circular tensions can be identified from institutional-industrial and organisational-technical to ethical, normative and behavioural perspectives. Furthermore, evolutionary notions, such as path dependencies, industrial inertia and lock-in, can provide guidance to identify the sources of circular tensions.

Institutional-industrial CE envisions structural change in institutions and industries which does not follow a smooth process and does not result in harmonious advances of all elements within the system. Institutions tend to adopt CE-based regulations and structures according to the particularity of their geopolitical, industrial and social context. Different degrees of capabilities allow industries to explore different aspects of $\mathrm{CE}$; some traditional industries might witness the effect of path dependency and lock-in through transformation more than emerging industries. All these differences can result in circular tensions, i.e. uneven developments within and between institutions and industries. Other sources of circular tensions can be linear market-related criteria and limitations (e.g. Peck et al. 2015), mal-investments (e.g. Korse et al. 2016; de Jesus and Mendonça 2018) or unsynchronised policies and regulations (Ilić and Nikolić 2016; Fletcher et al. 2018; García-Quevedo et al. 2020). Also, circular tensions relate to bottlenecks, such as a lack of required industrial infrastructure and capacity for the development of new production approaches. Moreover, traditional institutions and regulatory systems are influenced by dominating industrial systems which shape the regulation (e.g. tax systems, governmental subsidiaries) to be in favour of their development (see, e.g., Kinnunen and Kaksonen 2019). Consequently, changing some parts of institutional systems will result in misalignment with dominant parts and the creation of circular tensions.

Organisational-technical circular tensions can occur due to the implementation of conflicting organisational and technical innovations (see, e.g., Franco 2017; Linder and Williander 2017). For instance, the development of technologies to remanufacture products can hardly fit into existing linear organisational structures. Similarly, lock-in mechanisms, such as dominant linear technologies and design methodologies, hinder the diffusion of innovative circular business models. Further, historically technological change is an evolutionary process, following incremental improvements in existing technological systems. However, such incremental changes lead to circular tensions and time lag in the transformation process. Lastly, firms' business models create circular tensions when faced with the dilemma of choice between capturing new circular values and exploiting linear values at the same time (e.g. Rizos et al. 2016; Stål and Corvellec 2018).

Ethical, normative and behavioural circular tensions are inherent to transformation towards the CE; for instance, the dynamics of consumers' behaviour and the inertia caused by normative values and ethics in society create circular tensions (e.g. Liu et al. 2009). The CE may increase societal awareness and constantly expose new circular values, but sometimes these values are biased or controversial and result in circular tensions. One example is the development of markets for reused products via exporting to less developed countries without considering the dynamic of change in customers' behaviour and the lack of appropriate waste management systems locally.

The second part of the framework, Fig. 4, shows the dynamics of the interactions among the three evolutionary dimensions (flows of basic elements, circular tensions 
and systemic complementarities). In general, the transformation process consists of several transition stages that may result in changing the state of CE systems. This is driven by an uneven development of complementarities due to different system scopes as well as by transformation pressures within the system (i.e. CE development blocks). Thus, during the transformation process, the system experiences several imbalances due to the circular tensions. The types and degrees of circular tensions created and resolved depend to a large extent on the quality of entrepreneurship and institutional factors of the system. The system reaches a provisional balance stage when some parts of the system manage to change their industrial composition, firm structures, market arrangements and entrepreneurial skills. The state of the CE transitioning system can be measured by focusing on the circularity of the basic elements of the system, which are the flows of energy, material and economic value chains, and the evolution of societal values. Furthermore, we can study the dynamic pattern of change in the CE's economic and ecological dimensions via this part of the system.

\section{Discussion}

The CE notion should be viewed as the nexus of ecological dynamics, such as material and energy flows, and evolutionary economic and industrial processes, where tensions and complementarities are central, as shown in Fig. 5.

The flow of materials within the boundary of the CE is highly dynamic and does not follow a single direction. Fellner et al. (2017) and Moreau et al. (2017) argue that the possibility of reducing the consumption of primary raw materials is limited, and point to the inadequate availability of secondary materials for the current volume of industrial

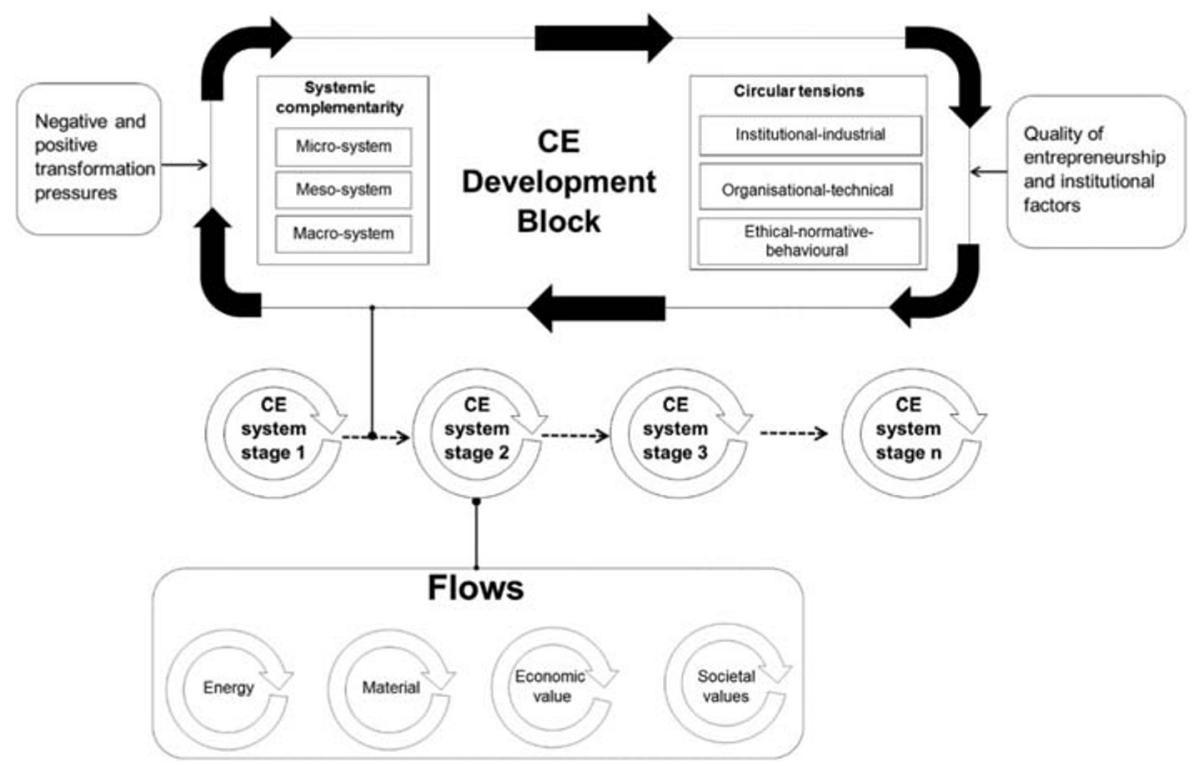

Fig. 4 The evolutionary dynamics of the transformation towards the CE 


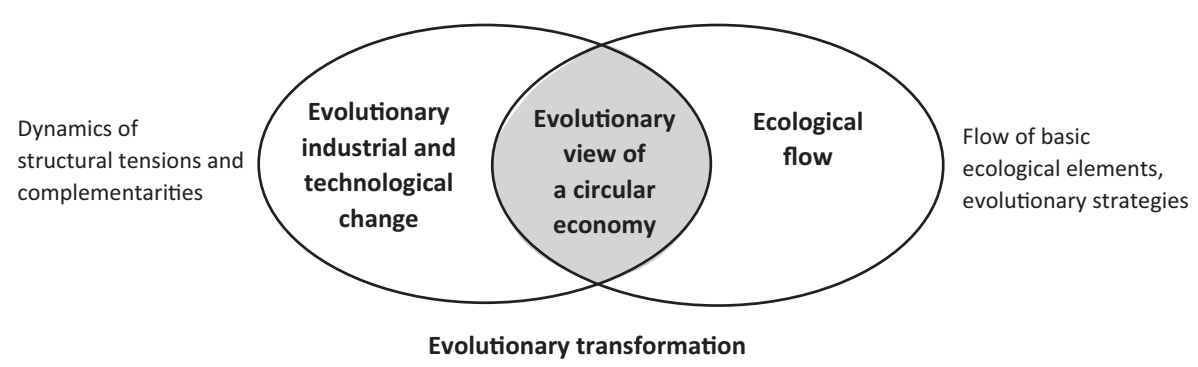

Fig. 5 Positioning of the framework in relation to evolutionary and ecological economics

production. Moreover, the quality and quantity of material recovery influence the actual flow of available secondary resources to the industry.

Balancing renewable resources flow and recycling of materials is deeply rooted in the CE vision. It is worth mentioning that scholars (e.g. Georgescu-Roegen 1977) refer to the "fourth law" and the increase of entropy in closed systems to ground the argument against the possibility of completely closing the energy and material flow loops. Critics of the "fourth law" (e.g. Ayres 1999) argue that the earth is an open system receiving the flow of infinite solar energy which can be used for closed-loop activities, since solar energy is not only renewable energy but an infinite energy source (Ghisellini et al. 2016; Korhonen et al. 2018b). However, Xia and Yang (2007) state that the "economic process is just a process to change valuable natural resource (low entropy) into waste (high entropy)". Moreover, the idea of designing much longerlasting products (reuse, remanufacture and recycling) would not always contribute to appropriate ecological flows of material and energy. Even long-lasting products that do not break down quickly at the end of their lifecycle consume more useful energy and release more entropy (Korhonen et al. 2018a).

When the CE is approached from an evolutionary perspective, it is almost impossible to avoid the substantial role of time and space. Thus, applying the systemic longterm approach to assessing the short-term, mid-term and long-term environmental impacts of circular efforts and their contribution to global net sustainability will become a big issue (Korhonen et al. 2018a; Schroeder 2018). The history of implementing environmentally friendly practices tells us that there is a tendency to displace/shift (e.g. geographically or temporally) the problem or simply change the nature of the initial problem. Thus, there is a need for a systematic and evolutionary perspective to understand these impacts, such as the "boomerang effect", by taking into account proper system boundaries and the systemic and evolving nature of the problem. In the same way, overlooking the dynamics of societal factors and their influence on the transition process to the CE might result in negative effects on consumption and on the economic scale of the CE, such as the "rebound effect", i.e. the net increase in the production and overall consumption of resources, and the creation of waste (Bocken et al. 2017a; Zink and Geyer 2017).

The evolutionary and dynamic aspects of economic values and new market dynamics are also reflected in $\mathrm{CE}$ principles. The $\mathrm{CE}$ generates new economic value through new mechanisms to create, deliver and capture circular values. It retrieves the value (material and embedded energy) that is added to the products through value chains by value retention activities (Reike et al. 2018a). In essence, the dynamic flow of 
economic value is in line with the scarcity of natural resources, as well as with the quality and availability of secondary materials which create the dynamics of market demands and prices (Reike et al. 2018b). Nevertheless, the current pricing mechanism is non-completed, which means that it mainly concerns the time value of acquiring and not the time value of the formation of the natural resources. Furthermore, government intervention and normative aspects of society can reshape the pricing mechanism of natural resources and economic value, known as endogenous evolution in the CE (Jiang and Chen 2010). Moreover, current pricing mechanisms of natural resources encourage industrial actors to leverage the price based on resource depletion. Thus, the CE paradigm can bring changes in pricing mechanisms, which are the powerful triggers for reducing natural resource consumption via technological innovation and the utilisation of secondary materials.

The other two dimensions of the framework are based on the evolutionary concepts of structural tensions and complementarities from DB theory, explaining the dynamics of industrial transformation. We have discussed these two concepts in the context of the $\mathrm{CE}$, and have explained the particularity of systemic complementarities and circular tensions. One example of a circular tension could be the conflicts between available production technologies and business models with circular design approaches. Similarly, systemic complementarities can be identified when, at meso level, infrastructures are not suitable or sufficiently developed for fostering the implementation CE strategies such as zero-waste production systems or closed-loop material supply chains. Moreover, each transformation process ends with the elimination of structural tensions and the emergence of key complementarities within the system. Also, from the ecological dimension, the state of the CE system transitioning can be measured by focusing on the achieved degree of circularity of the basic elements of the system, which are the flows of energy, material and economic value chains, and the evolution of societal values.

The three dimensions covered by the proposed framework - i.e. flows of basic elements, circular tensions and systemic complementarities - can be used to set the boundaries of future transformation studies in the context of the CE from either the ecological (flows of essential elements) or economic (systemic complementarities and structural tensions) perspectives. In this way, researchers in the CE field can consistently determine the boundaries of their studies concerning evolutionary and systemic aspects of CEs, which is an essential element for referencing existing knowledge by researchers, practitioners and policymakers. Hence, the framework may act as a guide, showing the most relevant entities, variables, relationships and levels of interaction that are compatible with the objectives of the study or action. Once the boundaries of problems and the aims of the study are set, the entities and the critical relationships between entities can be easily identified within the three-dimensional framework.

\section{Final remarks and avenues for future research}

This paper aimed to discuss the transformation towards the CE from an evolutionary perspective, proposing the DB (Dahmén 1950) as an analytical framework. The CE is an approach based on the need to mitigate climate change and calls for actions to transform the dominant linear economic system, which is pushing biological limits as a 
consequence of massive resource consumption and environmental pollution. In the industrial policy debate and in the engineering sciences, this is billed as a paradigmatic shift from the linear model towards a circular one. It acknowledges the fact that economic development cannot progress without considering fundamental laws and principles of ecology.

However, in this paper we have argued that in order to realise the full adoption potential of the $\mathrm{CE}$, it is important to consider and integrate the evolutionary patterns of industrial change. Although absent in the CE debate, this is not new (Costanza and Daly 1987,Costanza et al. 1997; Daly 1991). As already argued by Boulding (1966a) in his essay "The Economics of the Coming Spaceship Earth", and later by Boulding (1992) in "Towards a New Economics", an industrial system is an open, dynamic, evolving system that is not isolated from natural ecosystems. Moreover, the ecological principles and evolutionary patterns of system development, as discussed by Ring (1997), are reflected in the CE, starting from the notion that economic development cannot progress without considering the fundamental laws and principles of ecological evolution.

The linear production model has left a heritage of an unsustainable socio-economic system. As a sustainable alternative, the CE has gained popularity among politicians and businesses due to its vision of a regeneration of economic values in materials, the elimination of environmental damage and the creation of social benefits. The global industrial-economic system is in an ongoing transition process, and the $\mathrm{CE}$ is not achievable by individual attempts to change a firm's business model. In order to be fully realised, the CE involves a systemic change throughout the firm, industry or economy, and requires a radical shift in societal values, norms and behaviours. Thus the $\mathrm{CE}$ is also about understanding and overcoming tensions that might bring transformative pressures. This is where the DB framework comes in.

Although the emerging CE literature within the engineering and natural sciences has enriched our understanding, both conceptually (e.g. Masi et al. 2017; PrietoSandoval et al. 2018) and empirically (e.g. Mathews and Tan 2011; Bocken et al. $2017 b$ ), the importance of viewing this transition in the context of industrial and economic transformation processes has not yet been addressed satisfactorily. The transition towards the CEcannot be successful if the structural tensions on the prevailing system are not fully understood. Similarly to what has been experienced with previous radical industrial changes, the transformation towards the CE will certainly feature path dependencies (Partha and David 1994; Arthur 1989, 1990), path creation (Garud and Karnoe 2001; Stack and Gartland 2003), and inertia or lock-in (Liebowitz and Margolis 1995).

This paper is among the first attempts to discuss the CE from an evolutionary perspective in the context of industrial transformation. Thus, it needs to be considered in the light of further conceptual and theoretical improvements. To this end, we suggest that future studies apply the framework and the evolutionary theory in different empirical contexts of CE implementation. Specifically, we encourage case studies focusing on different political and institutional contexts. Further, the concepts of circular tension and systemic complementarities can be applied to various scopes to identify unpredictable dependencies and tensions within and between the dominant linear and emerging circular economic systems. 
Acknowledgements We gratefully acknowledge the constructive and helpful feedback of the editor of this journal and the two anonymous reviewers whose valuable suggestions have considerably improved this paper.

Funding Open access funding provided by Politecnico di Milano within the CRUI-CARE Agreement.

\section{Compliance with ethical standards}

Conflict of interest The authors declare that they have no conflict of interest.

Open Access This article is licensed under a Creative Commons Attribution 4.0 International License, which permits use, sharing, adaptation, distribution and reproduction in any medium or format, as long as you give appropriate credit to the original author(s) and the source, provide a link to the Creative Commons licence, and indicate if changes were made. The images or other third party material in this article are included in the article's Creative Commons licence, unless indicated otherwise in a credit line to the material. If material is not included in the article's Creative Commons licence and your intended use is not permitted by statutory regulation or exceeds the permitted use, you will need to obtain permission directly from the copyright holder. To view a copy of this licence, visit http://creativecommons.org/licenses/by/4.0/.

\section{References}

de Abreu MCS, Ceglia D (2018) On the implementation of a circular economy: the role of institutional capacity-building through industrial symbiosis. Resour Conserv Recycl 138(June):99-109. https://doi. org/10.1016/j.resconrec.2018.07.001

Allenby B (1998) Environmental security as a case study in industrial ecology. J Ind Ecol 2(1):45-60. https:// doi.org/10.1162/jiec.1998.2.1.45

Andersen AD, Markard J (2020) Multi-technology interaction in socio-technical transitions: how recent dynamics in HVDC technology can inform transition theories. Technol Forecast Soc Chang 151(October 2019):119802. https://doi.org/10.1016/j.techfore.2019.119802

Andrews D (2015) The circular economy, design thinking and education for sustainability. Local Econ 30(3): 305-315. https://doi.org/10.1177/0269094215578226

Arthur NWB (1989) Competing technologies, increasing returns, and lock-in by historical events. Economic Journal 99:116-131

Arthur NWB (1990) Positive feedbacks in the economy. ScientificAmerican 262(February):92-99

Atlason RS, Giacalone D, Parajuly K (2017) Product design in the circular economy: users' perception of endof-life scenarios for electrical and electronic appliances. J Clean Prod 168:1059-1069. https://doi.org/10. 1016/j.jclepro.2017.09.082

Ayres RU (1999) The second law, the fourth law, recycling and limits to growth. Ecol Econ 29(3):473-483. https://oi.org/10.1016/S0921-8009(98)00098-6

Baldassarre B, Schepers M, Bocken N, Cuppen E, Korevaar G, Calabretta G (2019) Industrial Symbiosis: towards a design process for eco-industrial clusters by integrating circular economy and industrial ecology perspectives. J Clean Prod 216:446-460. https://doi.org/10.1016/j.jclepro.2019.01.091

Bergek A, Hekkert M, Jacobsson S, Markard J, Sandén B, Truffer B (2015) Technological innovation systems in contexts: conceptualizing contextual structures and interaction dynamics. Environmental Innovation and Societal Transitions 16:51-64. https://doi.org/10.1016/j.eist.2015.07.003

Bergek A, Jacobsson S, Carlsson B, Lindmark S, Rickne A (2008) Analyzing the functional dynamics of technological innovation systems: a scheme of analysis. Res Policy 37(3):407-429. https://doi.org/10. 1016/j.respol.2007.12.003

Berggren C, Magnusson T, Sushandoyo D (2015) Transition pathways revisited: established firms as multilevel actors in the heavy vehicle industry. Res Policy 44(5):1017-1028. https://doi.org/10.1016/j.respol. 2014.11.009

Bidmon CM, Knab SF (2018) The three roles of business models in societal transitions: new linkages between business model and transition research. J Clean Prod 178:903-916. https://doi.org/10.1016/j.jclepro.2017. 12.198 
Blomsma F, Brennan G (2017) The emergence of circular economy: a new framing around prolonging resource productivity. J Ind Ecol 21(3):603-614. https://doi.org/10.1111/jiec.12603

Bobba S, Mathieux F, Ardente F, Blengini GA, Cusenza MA, Podias A, Pfrang A (2018) Life cycle assessment of repurposed electric vehicle batteries: an adapted method based on modelling energy flows. Journal of Energy Storage 19:213-225. https://doi.org/10.1016/j.est.2018.07.008

Bocken NMP, Short SW (2016) Towards a sufficiency-driven business model: experiences and opportunities. Environmental Innovation and Societal Transitions 18:41-61. https://doi.org/10.1016/j.eist.2015.07.010

Bocken NMP, de Pauw I, Bakker C, van der Grinten B (2016) Product design and business model strategies for a circular economy. J Ind Prod Eng 33(5):308-320. https://doi.org/10.1080/21681015.2016.1172124

Bocken NMP, Olivetti EA, Cullen JM, Potting J, Lifset R (2017a) Taking the circularity to the next level: a special issue on the circular economy. J Ind Ecol 21(3):476-482. https://doi.org/10.1111/jiec.12606

Bocken NMP, Ritala P, Huotari P (2017b) The circular economy: exploring the introduction of the concept among S\&P 500 firms. J Ind Ecol 21(3):487-490. https://doi.org/10.1111/jiec.12605

Boulding KE (1966a) The economics of the coming spaceship earth. In: Jarrett H (ed) Environmental quality issues in a growing economy. Johns Hopkins University Press, Baltimore

Boulding KE (1966b) Environmental quality in a growing economy. Johns Hopkins Press, Baltimore

Boulding KE (1981) Evolutionary economics. Sage, London

Boulding KE (1992) Towards a new economics - critical essays on ecology, distribution and other themes. Edward Elgar Publishing, Vermont

Bukhari MA, Carrasco-Gallego R, Ponce-Cueto E (2018) Developing a national programme for textiles and clothing recovery. Waste Manag Res 0734242X1875919. https://doi.org/10.1177/0734242X18759190

Bundgaard AM, Huulgaard RD (2019) Luxury products for the circular economy? A case study of Bang \& Olufsen. Bus Strateg Environ 28(5):699-709. https://doi.org/10.1002/bse.2274

Campbell-Johnston K, ten Cate J, Elfering-Petrovic M, Gupta J (2019) City level circular transitions: barriers and limits in Amsterdam, Utrecht and the Hague. J Clean Prod 235:1232-1239. https://doi.org/10.1016/j. jclepro.2019.06.106

Cavalcanti M, De Abreu S, Ceglia D (2018) Resources, Conservation \& Recycling On the implementation of a circular economy : The role of institutional capacity-building through industrial symbiosis. Resources, Conservation \& Recycling 138(June):99-109. https://doi.org/10.1016/j.resconrec.2018.07.001

Carlsson, B. (1997). Introduction in Carlsson B. (ed.) technological systems and industrial dynamics, Kluwer academic publishers

Centobelli P, Cerchione R, Chiaroni D, Del Vecchio P, Urbinati A (2020) Designing business models in circular economy: a systematic literature review and research agenda. Bus Strateg Environ 29(4):17341749. https://doi.org/10.1002/bse.2466

Chen LH, Hung P, Ma HW (2020, June 2019) Integrating circular business models and development tools in the circular economy transition process: A firm-level framework. Bus Strateg Environ:1-12. https://doi. org/10.1002/bse. 2477

Ciulli, F., Kolk, A., \& Boe-Lillegraven, S. (2019). Circularity Brokers: Digital Platform Organizations and Waste Recovery in Food Supply Chains. In Journal of Business Ethics. https://doi.org/10.1007/s10551019-04160-5

Commoner B (1971) The closing circle: nature, man, and technology. Alfred A. Knopf, New York

Costanza R, Daly HE (1987) Toward an ecological economics. Ecol Model 38:1-7

Costanza R, Cumberland J, Daly H, Goodland R, Norgaard R (1997) An introduction to ecological economics. St. Lucie Press, Florida

Corcelli F, Ripa M, Leccisi E, Cigolotti V, Fiandra V, Graditi G et al (2018) Sustainable urban electricity supply chain - indicators of material recovery and energy savings from crystalline silicon photovoltaic panels end-of-life. Ecol Indic 94:37-51. https://doi.org/10.1016/j.ecolind.2016.03.028

Cyrs WD, Avens HJ, Capshaw ZA, Kingsbury RA, Sahmel J, Tvermoes BE (2014) Landfill waste and recycling: use of a screening-level risk assessment tool for end-of-life cadmium telluride (CdTe) thin-film photovoltaic (PV) panels. Energy Policy 68:524-533. https://doi.org/10.1016/j.enpol.2014.01.025

D'Amato D, Droste N, Winkler KJ, Toppinen A (2019) Thinking green, circular or bio: eliciting researchers' perspectives on a sustainable economy with Q method. J Clean Prod 230:460-476. https://doi.org/10. 1016/j.jclepro.2019.05.099

Dahmén E (1950) Svensk industriell företagarverksamhet. In: Kausalanalys av den industriella utvecklingen 1919-1939, doktorsavhandling. Stockholm, Industriens Utredningsinstitut

Dahmén E (1984) Schumpeterian dynamics. J Econ Behav Organ 5(1):25-34

Dahmén E (1988) Development blocks' in industrial economics'. Scand Econ Hist Rev 36(1):3-14. https:// doi.org/10.1080/03585522.1988.10408102 
Daae J, Chamberlin L, Boks C (2019) Dimensions of behaviour change in the context of designing for a circular economy dimensions of behaviour change in the context of designing for a circular economy. Des J 21(4):521-541. https://doi.org/10.1080/14606925.2018.1468003

Dalhammar, C. (2019). Towards a hierarchy of consumption behaviour in the circular economy. 26(3), 394 420. https://doi.org/10.1177/1023263X19840943

Daly HE (1991) Steady-state economics (2nd ed.). Island Press, Washington, DC

Daly HE (1996) Beyond growth: the economics of sustainable development. Beacon Press, Boston

de Aguiar J, de Oliveira L, da Silva JO, Bond D, Scalice RK, Becker D (2017) A design tool to diagnose product recyclability during product design phase. J Clean Prod 141:219-229. https://doi.org/10.1016/j. jclepro.2016.09.074

De Angelis R, Feola R (2020) Circular business models in biological cycles: the case of an Italian spin-off. J Clean Prod 247:119603. https://doi.org/10.1016/j.jclepro.2019.119603

de Jesus A, Mendonça S (2018) Lost in transition? Drivers and barriers in the eco-innovation road to the circular economy. Ecol Econ 145(July 2017):75-89. https://doi.org/10.1016/j.ecolecon.2017.08.001

De Los Rios IC, Charnley FJS (2017) Skills and capabilities for a sustainable and circular economy: the changing role of design. J Clean Prod 160:109-122. https://doi.org/10.1016/j.jclepro.2016.10.130

Demirel P, Danisman GO (2019) Eco-innovation and firm growth in the circular economy: evidence from European small- and medium-sized enterprises. Bus Strateg Environ 28(8):1608-1618. https://doi.org/10. $1002 /$ bse. 2336

Dosi G, Nelson R (1993) Evolutionary theories in economics. International Institute for Applied Systems Analysis, Laxenburg

Domínguez A, Geyer R (2017) Photovoltaic waste assessment in Mexico. Resour Conserv Recycl 127(February):29-41. https://doi.org/10.1016/j.resconrec.2017.08.013

Ellen MacArthur Foundation (2016). Money makes the world go round (and will it help to make the economy circular as well?). Ellen MacArthur Foundation, 126

Elzinga R, Reike D, Negro SO, Boon WPC (2020) Consumer acceptance of circular business models. J Clean Prod 254:119988. https://doi.org/10.1016/j.jclepro.2020.119988

Enflo K, Kander A, Schön L (2008) Identifying development blocks-a new methodology : IIIImplemented on Swedish industry 1900-1974. J Evol Econ 18(1):57-76. https://doi.org/10.1007/s00191-007-0070-8

Erixon L (2011) Development blocks, malinvestment and structural tensions-the Kerman-Dahmén theory of the business cycle. J Inst Econ 7(1):105-129. https://doi.org/10.1017/S1744137410000196

Fellner J, Lederer J, Scharff C, Laner D (2017) Present potentials and limitations of a circular economy with respect to primary raw material demand. J Ind Ecol 21(3):494-496. https://doi.org/10.1111/jiec.12582

Ferronato N, Rada EC, Gorritty Portillo MA, Cioca LI, Ragazzi M, Torretta V (2018) Introduction of the circular economy within developing regions: a comparative analysis of advantages and opportunities for waste valorization. J Environ Manag 230(September 2018):366-378. https://doi.org/10.1016/j.jenvman. 2018.09.095

Fischer-Kowalski M, Haberl H (1998) Sustainable develop- ment: socio-economic metabolism and colonization of nature. Int Soc Sci J 50:573-587

Fletcher, C. A., Hooper, P. D., \& Dunk, R. M. (2018). Unintended consequences of secondary legislation: A case study of the UK landfill tax (qualifying fines) order 2015. Resources, Conservation and Recycling, 138(February), 160-171. https://doi.org/10.1016/j.resconrec.2018.07.011

Franco MA (2017) Circular economy at the micro level: a dynamic view of incumbents' struggles and challenges in the textile industry. J Clean Prod 168:833-845. https://doi.org/10.1016/j.jclepro.2017.09. 056

Freeman C (1974) The economics of industrial innovation. Penguin, Harmondsworth

Freeman C (1994) The economics of technical change. Camb J Econ 18(5):463-514

Frei, R., Jack, L., \& Krzyzaniak, S. A. (2020). Sustainable reverse supply chains and circular economy in multichannel retail returns. Business Strategy and the Environment, (august 2019), 1-16. https://doi.org/ $10.1002 /$ bse. 2479

García-Quevedo, J., Jové-Llopis, E., \& Martínez-Ros, E. (2020). Barriers to the circular economy in European small and medium-sized firms. Business Strategy and the Environment, (September 2019), 1-15. https:// doi.org/10.1002/bse. 2513

Garud, R., and Karnoe P. (2001) "Path dependence and creation." In Path Depen R. Garud and P. Karnoe. London: Lawrence Erlbaum Associates

Gaustad G, Krystofik M, Bustamante M, Badami K (2018) Circular economy strategies for mitigating critical material supply issues. Resour Conserv Recycl 135. https://doi.org/10.1016/j.resconrec.2017.08.002

Geels, F. W. (2002). Technological transitions as evolutionary reconfiguration processes : a multi-level perspective and a case-study. 31, 1257-1274 
Geels FW (2010) Ontologies, socio-technical transitions (to sustainability), and the multi-level perspective. Res Policy 39(4):495-510. https://doi.org/10.1016/j.respol.2010.01.022

Geels FW (2011) The multi-level perspective on sustainability transitions: responses to seven criticisms. Environmental Innovation and Societal Transitions 1(1):24 40. https://doi.org/10.1016/j.eist.2011.02.002

Geerken T, Schmidt J, Boonen K, Christis M, Merciai S (2019) Assessment of the potential of a circular economy in open economies - case of Belgium. J Clean Prod 227:683-699. https://doi.org/10.1016/j. jclepro.2019.04.120

Geissdoerfer M, Savaget P, Bocken NMP, Hultink EJ (2017) The circular economy - a new sustainability paradigm? J Clean Prod 143:757-768. https://doi.org/10.1016/J.JCLEPRO.2016.12.048

Genovese A, Acquaye AA, Figueroa A, Koh SCL (2017) Sustainable supply chain management and the transition towards a circular economy: evidence and some applications. Omega (United Kingdom) 66: 344-357. https://doi.org/10.1016/j.omega.2015.05.015

Georgescu-Roegen N (1977) The steady state and ecological salvation (1977): a thermodynamic analysis. From Bioeconomics to Degrowth: Georgescu-Roegen's New Economics in Eight Essays 27(4):93-102. https://doi.org/10.4324/9780203830413

Ghisellini P, Cialani C, Ulgiati S (2015) A review on circular economy: the expected transition to a balances interplay of environment and economic systems. J Clean Prod 114:2015-2018. https://doi.org/10.1016/j. jclepro.2015.09.007

Ghisellini P, Cialani C, Ulgiati S (2016) A review on circular economy: the expected transition to a balanced interplay of environmental and economic systems. J Clean Prod 114:11-32. https://doi.org/10.1016/j. jclepro.2015.09.007

Giampietro M (2019) On the circular bioeconomy and decoupling: implications for sustainable growth. Ecol Econ 162(April):143-156. https://doi.org/10.1016/j.ecolecon.2019.05.001

Gönen Ç, Kaplanoğlu E (2019) Environmental and economic evaluation of solar panel wastes recycling. Waste Management and Research 37(4):412-418. https://doi.org/10.1177/0734242X19826331

Govindan K, Hasanagic M (2018) A systematic review on drivers, barriers, and practices towards circular economy: a supply chain perspective. Int J Prod Res 56(1-2):278-311. https://doi.org/10.1080/00207543. 2017.1402141

Graedel TE, Allenby BR (1995) Industrial ecology. Prentice Hall, Englewood Cliffs. https://doi.org/10.1080/ 03085147.2015 .1013353

Gregson N, Crang M, Fuller S, Holmes H (2015) Interrogating the circular economy: the moral economy of resource recovery in the EU. Econ Soc 44(2):218-243. https://doi.org/10.1080/03085147.2015.1013353

Grundmann V, Bilitewski B, Zehm A, Darbra RM, Barceló D (2013) Risk-based management of chemicals and products in a circular economy at a global scale- impacts of the FP7 funded project RISKCYCLE. Environ Sci Eur 25(1):2-7. https://doi.org/10.1186/2190-4715-25-14

Guo B, Geng Y, Sterr T, Zhu Q, Liu Y (2017) Investigating public awareness on circular economy in western China: a case of Urumqi Midong. J Clean Prod 142:2177-2186. https://doi.org/10.1016/j.jclepro.2016.11. 063

Haley B (2018) 'Integrating structural tensions into technological innovation systems analysis: application to the case of transmission interconnections and renewable electricity in Nova Scotia, Canada', research policy. Elsevier 47(6):1147-1160. https://doi.org/10.1016/j.respol.2018.04.004

Heyes G, Sharmina M, Mendoza JMF, Gallego-Schmid A, Azapagic A (2018) Developing and implementing circular economy business models in service-oriented technology companies. J Clean Prod 177:621-632. https://doi.org/10.1016/j.jclepro.2017.12.168

Hofmann F (2019) Circular business models: business approach as driver or obstructer of sustainability transitions? J Clean Prod 224:361-374. https://doi.org/10.1016/j.jclepro.2019.03.115

Hughes TP (1983) Networks of power: electrification in Western society, 1880-1930. Johns Hopkins University Press, Baltimore

Hughes, T. (1992) The Dynamics of Technological Change: Salients, Reverse Salients and Critical Problems, in Dosi, G. Gianetti, R. and Toninelli, P.A. eds (1992) Technology and Enterprise in Historical Perspective, Oxford: Clarendon Press

Ilić M, Nikolić M (2016) Drivers for development of circular economy - a case study of Serbia. Habitat International 56:191-200. https://doi.org/10.1016/j.habitatint.2016.06.003

Jabbour CJC, De Sousa Jabbour ABL, Govindan K, De Freitas TP, Soubihia DF, Kannan D, Latan H (2016) Barriers to the adoption of green operational practices at Brazilian companies: effects on green and operational performance. Int J Prod Res 54(10):3042-3058. https://doi.org/10.1080/00207543.2016. 1154997

Jackson M, Lederwasch A, Giurco D (2014) Transitions in theory and practice: managing metals in the circular economy. Resources 3(3):516-543. https://doi.org/10.3390/resources3030516 
Jiang GG, Chen J (2010) Research on driving force of circular economy endogenous evolution from Price mechanism angle. Adv Mater Res 113-116:181-184. https://doi.org/10.4028/www.scientific.net/AMR. 113-116.181

Jiao W, Boons F (2014) Toward a research agenda for policy intervention and facilitation to enhance industrial symbiosis based on a comprehensive literature review. J Clean Prod 67:14-25. https://doi.org/10.1016/j. jclepro.2013.12.050

Jiao W, Boons F (2017) Policy durability of circular economy in China: a process analysis of policy translation. Resour Conserv Recycl 117:12-24. https://doi.org/10.1016/j.resconrec.2015.10.010

Kalmykova, Y., Sadagopan, M., \& Rosado, L. (2018) Circular economy - from review of theories and practices to development of implementation tools. Resources, Conservation and Recycling, 135(February 2017), 190-201. https://doi.org/10.1016/j.resconrec.2017.10.034

Karakaya E, Nuur C, Assbring L (2018) Potential transitions in the iron and steel industry in Sweden : towards a hydrogen-based future? J Clean Prod 195:651-663. https://doi.org/10.1016/j.jclepro.2018.05.142

Kemp R, Schot J, Hoogma R (1998) Regime shifts to sustainability through processes of niche formation: the approach of strategic niche management. Technology Analysis and Strategic Management 10(2):175198. https://doi.org/10.1080/09537329808524310

Keynes JM (1937) The general theory of employment. Q J Econ 51(2):209-223

Khan O, Daddi T, Iraldo F (2020) Microfoundations of dynamic capabilities: insights from circular economy business cases. Bus Strateg Environ 29(3):1479-1493. https://doi.org/10.1002/bse.2447

King AM, Burgess SC, Ijomah W, Mcmahon CA (2006) Remanufacture or Recycle ? Sustain Dev 14(December 2005):257-267

Kinnunen PHM, Kaksonen AH (2019) Towards circular economy in mining: opportunities and bottlenecks for tailings valorization. J Clean Prod 228:153-160. https://doi.org/10.1016/j.jclepro.2019.04.171

Kirchherr J, Reike D, Hekkert M (2017) Conceptualizing the circular economy: an analysis of 114 definitions. Resour Conserv Recycl 127(April):221-232. https://doi.org/10.1016/j.resconrec.2017.09.005

Kjaer LL, Pigosso DCA, Niero M, Bech NM, McAloone TC (2019) Product/Service-Systems for a Circular Economy: the route to decoupling economic growth from resource consumption? J Ind Ecol 23(1):22-35. https://doi.org/10.1111/jiec.12747

Klein BH (1984) Prices. A Dynamic Theory. New York, Pergamon Press, Wages and Business Cycles

Korhonen J, Honkasalo A, Seppälä J (2018a) Circular economy: the concept and its limitations. Ecol Econ 143:37-46. https://doi.org/10.1016/j.ecolecon.2017.06.041

Korhonen J, Nuur C, Feldmann A, Birkie SE (2018b) Circular economy as an essentially contested concept. J Clean Prod 175:544-552. https://doi.org/10.1016/j.jclepro.2017.12.111

Korse M, Ruitenburg RJ, Toxopeus ME, Braaksma AJJ (2016) Embedding the circular economy in investment decision-making for capital assets - a business case framework. Procedia CIRP 48:425-430. https:// doi.org/10.1016/j.procir.2016.04.087

Kühl C, Bourlakis M, Aktas E, Skipworth H (2019) How does servitisation affect supply chain circularity? - a systematic literature review. J Enterp Inf Manag. https://doi.org/10.1108/JEIM-01-2019-0024

Kuokkanen, H., \& Sun, W. (2019). Companies, Meet Ethical Consumers: Strategic CSR Management to Impact Consumer Choice. In Journal of Business Ethics. https://doi.org/10.1007/s10551-019-04145-4

Lacasa E, Santolaya JL, Biedermann A (2016) Obtaining sustainable production from the product design analysis. J Clean Prod 139:706-716. https://doi.org/10.1016/j.jclepro.2016.08.078

Lewandowski M (2016) Designing the business models for circular economy-towards the conceptual framework. Sustainability (Switzerland) 8(1):1-28. https://doi.org/10.3390/su8010043

Li W (2011) Comprehensive evaluation research on circular economic performance of eco-industrial parks. Energy Procedia 5:1682-1688. https://doi.org/10.1016/j.egypro.2011.03.287

Liebowitz SJ, Margolis SE (1995) Path dependence, lock-in, and history. J Law Econ Organ 11(1):205-226

Lieder M, Rashid A (2016) Towards circular economy implementation: a comprehensive review in context of manufacturing industry. J Clean Prod 115:36-51. https://doi.org/10.1016/j.jclepro.2015.12.042

Linder M, Williander M (2017) Circular business model innovation: inherent uncertainties. Bus Strateg Environ 26(2):182-196. https://doi.org/10.1002/bse.1906

Liu Q, Li HM, Zuo XL, Zhang FF, Wang L (2009) A survey and analysis on public awareness and performance for promoting circular economy in China: a case study from Tianjin. J Clean Prod 17(2): 265-270. https://doi.org/10.1016/j.jclepro.2008.06.003

Lyle, J.T., (1994). Regenerative Design for Sustainable Development. John Wiley \& Sons, New York; Chichester

Makov T, Font Vivanco D (2018) Does the circular economy grow the pie? The case of rebound effects from smartphone reuse. Frontiers in Energy Research 6(May):1-11. https://doi.org/10.3389/fenrg.2018.00039 
Marcela, C., \& Morales, B. (2020). Circular economy in Latin America : A systematic literature review. (January), 1-19. https://doi.org/10.1002/bse.2515

Markard J, Raven R, Truffer B (2012) Sustainability transitions: an emerging field of research and its prospects. Res Policy 41(6):955-967. https://doi.org/10.1016/j.respol.2012.02.013

Marshall A (1920) Principles of economics (8th edition), vol 1. Macmillan and Co., Ltd., London

Martins NO (2018) The classical circular economy, Sraffian ecological economics and the capabilities approach. Ecol Econ 145(August 2017):38-45. https://doi.org/10.1016/j.ecolecon.2017.08.026

Masi D, Day S, Godsell J (2017) Supply chain configurations in the circular economy: a systematic literature review. Sustainability (Switzerland) 9(9). https://doi.org/10.3390/su9091602

Mathews JA, Tan H (2011) Progress toward a circular economy in China: the drivers (and inhibitors) of ecoindustrial initiative. J Ind Ecol 15(3):435-457. https://doi.org/10.1111/j.1530-9290.2011.00332.x

Matus KJM, Xiao X, Zimmerman JB (2012) Green chemistry and green engineering in China: drivers, policies and barriers to innovation. J Clean Prod 32:193-203. https://doi.org/10.1016/j.jclepro.2012.03. 033

McDonough W, Braungart M (2002) Cradle to cradle: remaking the way we make things, first edn. North Point Press, New York

McDowall W, Geng Y, Huang B, Barteková E, Bleischwitz R, Türkeli S et al (2017) Circular economy policies in China and Europe. J Ind Ecol 21(3):651-661. https://doi.org/10.1111/jiec.12597

Meadows D, Meadows D, Randers J, Behrens W (1972) The limits to growth. New York. https://doi.org/10. 1111/j.1752-1688.1972.tb05230.x

Milios L (2017) Advancing to a circular economy: three essential ingredients for a comprehensive policy mix. Sustain Sci:1-18. https://doi.org/10.1007/s11625-017-0502-9

Milios L, Matsumoto M (2019) Consumer perception of remanufactured automotive parts and policy implications for transitioning to a circular economy in Sweden. Sustainability (Switzerland) 11(22). https://doi.org/10.3390/su11226264

Millar N, McLaughlin E, Börger T (2019) The circular economy: swings and roundabouts? Ecol Econ 158(December 2018):11-19. https://doi.org/10.1016/j.ecolecon.2018.12.012

Mont O (2002) Clarifying the concept of product - service system. J Clean Prod 10:237-245. https://doi.org/ 10.1016/S0959-6526(01)00039-7

Moreau V, Sahakian M, van Griethuysen P, Vuille F (2017) Coming full circle: why social and institutional dimensions matter for the circular economy. J Ind Ecol 21(3):497-506. https://doi.org/10.1111/jiec.12598

Moreno, M., Rios, C. D. L., Rowe, Z., \& Charnley, F. (2016). A conceptual framework for circular design. $10.3390 /$ su8090937

Morseletto P (2020) Restorative and regenerative: exploring the concepts in the circular economy. J Ind Ecol: 1-11. https://doi.org/10.1111/jiec. 12987

Murray, A., Skene, K., \& Haynes, K. (2017). The circular Economy: An Interdisciplinary Exploration of the Concept and Application in a Global Context. Journal of Business Ethics. https://doi.org/10.1007/s10551015-2693-2

Nasir MHA, Genovese A, Acquaye AA, Koh SCL, Yamoah F (2017) Comparing linear and circular supply chains: a case study from the construction industry. Int J Prod Econ 183:443-457. https://doi.org/10.1016/ j.ijpe.2016.06.008

Nelson RR, Winter SG (1973) Toward an evolutionary theory of economic capabilities. Am Econ Rev 63(2): 440-449

Nelson RR, Winter SG (1982) An evolutionary theory of economic behavior and capabilities. Harvard University Press, Cambridge, pp 195-307

Norgaard RB (1981) Sociosystem and ecosystem coevolution in the Amazon. J Environ Econ Manag 8:238254

Niero M, Olsen SI (2016) Circular economy: to be or not to be in a closed product loop? A life cycle assessment of aluminium cans with inclusion of alloying elements. Resour Conserv Recycl 114:18-31. https://doi.org/10.1016/j.resconrec.2016.06.023

Novotny M, Laestadius S (2014) Beyond papermaking: technology and market shifts for wood-based biomass industries - management implications for large-scale industries. Technology Analysis and Strategic Management 26(8):875-891. https://doi.org/10.1080/09537325.2014.912789

Nuvolari A (2019) Understanding successive industrial revolutions: a "development block" approach. Environmental Innovation and Societal Transitions 32(October 2018):33-44. https://doi.org/10.1016/j. eist.2018.11.002

Pajunen N, Watkins G, Husgafvel R, Heiskanen K, Dahl O (2013) The challenge to overcome institutional barriers in the development of industrial residue based novel symbiosis products - experiences from Finnish process industry. Miner Eng 46-47:144-156. https://doi.org/10.1016/j.mineng.2013.03.008 
Pan SY, Du MA, Te Huang I, Liu IH, Chang EE, Chiang PC (2014) Strategies on implementation of waste-toenergy (WTE) supply chain for circular economy system: a review. J Clean Prod 108:409-421. https:// doi.org/10.1016/j.jclepro.2015.06.124

Park J, Sarkis J, Wu Z (2010) Creating integrated business and environmental value within the context of China's circular economy and ecological modernization. J Clean Prod 18(15):1492-1499. https://doi.org/ 10.1016/j.jclepro.2010.06.001

Parkins E (1930) The geography of American geographers. The Journal of Geography 33(9):229

Partha D, David PA (1994) Toward a new economics of science. Res Policy 23(5):487-521. https://doi.org/ 10.1016/0048-7333(94)01002-1

Patala S, Salmi A, Bocken N (2020) Intermediation dilemmas in facilitated industrial symbiosis. J Clean Prod 261:121093. https://doi.org/10.1016/j.jclepro.2020.121093

Peck D, Kandachar P, Tempelman E (2015) Critical materials from a product design perspective. Mater Des 65:147-159. https://doi.org/10.1016/j.matdes.2014.08.042

Penrose ET (1959) The theory of the growth of the firm. John Wiley, New York

Perey R, Benn S, Agarwal R, Edwards M (2018) The place of waste: changing business value for the circular economy. Bus Strateg Environ 27(5):631-642. https://doi.org/10.1002/bse.2068

Preston LE (1975) Corporation and society: the search for a paradigm. J Econ Lit:434-453

Potting J, Hekkert M, Worrell E, Hanemaaijer A (2017) Circular economy: measuring innovation in the product chain - policy report. PBL Netherlands Environmental Assessment Agency 2544:42

Prieto-Sandoval V, Jaca C, Ormazabal M (2018) Towards a consensus on the circular economy. J Clean Prod 179:605-615. https://doi.org/10.1016/j.jclepro.2017.12.224

Prosman EJ, Wæhrens BV, Liotta G (2017) Closing global material loops: initial insights into firm-level challenges. J Ind Ecol 21(3):641-650. https://doi.org/10.1111/jiec.12535

Quina MJ, Bontempi E, Bogush A, Schlumberger S, Weibel G, Braga R et al (2018) Technologies for the management of MSW incineration ashes from gas cleaning: new perspectives on recovery of secondary raw materials and circular economy. Sci Total Environ 635:526-542. https://doi.org/10.1016/j.scitotenv. 2018.04.150

Ranta V, Aarikka-Stenroos L, Ritala P, Mäkinen SJ (2018) Exploring institutional drivers and barriers of the circular economy: a cross-regional comparison of China, the US, and Europe. Resour Conserv Recycl 135(August 2017):70-82. https://doi.org/10.1016/j.resconrec.2017.08.017

Reh L (2013) Process engineering in circular economy. Particuology 11(2):119-133. https://doi.org/10.1016/j. partic.2012.11.001

Reike D, Vermeulen WJV, Witjes S (2018a) The circular economy: new or refurbished as CE 3.0? exploring controversies in the conceptualization of the circular economy through a focus on history and resource value retention options. Resour Conserv Recycl 135(August 2017):246-264. https://doi.org/10. 1016/j.resconrec.2017.08.027

Reike D, Vermeulen WJV, Witjes S (2018b) The circular economy: new or refurbished as CE 3.0? exploring controversies in the conceptualization of the circular economy through a focus on history and resource value retention options. Resour Conserv Recycl 135(August):246-264. https://doi.org/10.1016/j. resconrec.2017.08.027

Ring I (1997) Evolutionary strategies in environmental policy. Ecol Econ 23(3):237-249. https://doi.org/10. 1016/S0921-8009(97)00582-X

Rizos V, Behrens A, van der Gaast W, Hofman E, Ioannou A, Kafyeke T et al (2016) Implementation of circular economy business models by small and medium-sized enterprises (SMEs): barriers and enablers. Sustainability (Switzerland) 8(11). https://doi.org/10.3390/su8111212

Rosa P, Sassanelli C, Terzi S (2019) Towards circular business models: a systematic literature review on classification frameworks and archetypes. J Clean Prod 236:117696. https://doi.org/10.1016/j.jclepro. 2019.117696

Rotmans J, Loorbach D (2009) Complexity and transition management. J Ind Ecol 13(2):184-196. https://doi. org/10.1111/j.1530-9290.2009.00116.x

Ryen EG, Gaustad G, Babbitt CW, Babbitt G (2018) Ecological foraging models as inspiration for optimized recycling systems in the circular economy. Resour Conserv Recycl 135(August 2017):48-57. https://doi. org/10.1016/j.resconrec.2017.08.006

Saavedra YMB, Iritani DR, Pavan ALR, Ometto AR (2018) Theoretical contribution of industrial ecology to circular economy. J Clean Prod 170:1514-1522. https://doi.org/10.1016/j.jclepro.2017.09.260

Saidani M, Yannou B, Leroy Y, Cluzel F, Kendall A (2019) A taxonomy of circular economy indicators. J Clean Prod 207:542-559. https://doi.org/10.1016/j.jclepro.2018.10.014 
Sakai S, Yoshida H, Hirai Y, Asari M, Takigami H, Takahashi S et al (2011) International comparative study of 3R and waste management policy developments. Journal of Material Cycles and Waste Management 13(2):86-102. https://doi.org/10.1007/s10163-011-0009-x

Salvador R, Barros MV, da Luz LM, Piekarski CM, de Francisco AC (2020) Circular business models: current aspects that influence implementation and unaddressed subjects. J Clean Prod 250:119555. https://doi. org/10.1016/j.jclepro.2019.119555

Sauvé S, Bernard S, Sloan P (2016) Environmental sciences, sustainable development and circular economy: alternative concepts for trans-disciplinary research. Environmental Development 17:48-56. https://doi. org/10.1016/j.envdev.2015.09.002

Schalkwyk RF, Reuter MA, Gutzmer J, Stelter M (2018) Challenges of digitalizing the circular economy : assessment of the state-of-the-art of metallurgical carrier metal platform for lead and its associated technology elements. J Clean Prod 186:585-601. https://doi.org/10.1016/j.jclepro.2018.03.111

Schot J, Kanger L (2018) Deep transitions: emergence, acceleration, stabilization and directionality. Res Policy 47(6):1045-1059. https://doi.org/10.1016/j.respol.2018.03.009

Schroeder, P. (2018). The Relevance of Circular Economy Practices to the Sustainable Development Goals 00(0), 1-19. https://doi.org/10.1111/jiec.12732

Schumpeter, Joseph, 1939, Business cycles, Vol. I., New York: Mc Graw-Hill

Schumpeter J (1943/2000) Capitalism. Routledge, Socialism and Democracy, London \& New York

Sihvonen S, Ritola T (2015) Conceptualizing ReX for aggregating end-of-life strategies in product development. Procedia CIRP 29:639-644. https://doi.org/10.1016/j.procir.2015.01.026

Silva A, Rosano M, Stocker L, Gorissen L (2017) From waste to sustainable materials management: three case studies of the transition journey. Waste Manag 61:547-557. https://doi.org/10.1016/j.wasman.2016.11. 038

Simmonds PL (1862) Undeveloped substances: or, hints for enterprise in neglected fields. Robert Hardwicke, London

Smith A, Stirling A, Berkhout F (2005) The governance of sustainable socio-technical transitions. Res Policy 34(10):1491-1510. https://doi.org/10.1016/j.respol.2005.07.005

Sousa-Zomer TT, Magalhães L, Zancul E, Cauchick-Miguel PA (2018) Exploring the challenges for circular business implementation in manufacturing companies: an empirical investigation of a pay-per-use service provider. Resour Conserv Recycl 135. https://doi.org/10.1016/j.resconrec.2017.10.033

Stahel, W., Reday, G., (1976). The potential for substituting manpower for energy, Report to the Commission of the European Communities

Stahel, W., (1982). The product life factor. In: Orr, G.S. (Ed.), An inquiry into the nature of sustainable societies. The Role of the Private Sector. Houston Area Research Centre, Houston, pp. 72e105

Stahel, W. R. (2010). The performance economy: 2nd edition. In The Performance Economy: 2nd Edition. https://doi.org/10.1057/9780230274907

Stack M, Gartland M (2003) Path creation, path dependency, and alternative theories of the firm. Journal of Economic Issues 37(2):487-494

Stål HI, Corvellec H (2018) A decoupling perspective on circular business model implementation: illustrations from Swedish apparel. J Clean Prod 171:630-643. https://doi.org/10.1016/j.jclepro.2017.09.249

Su B, Heshmati A, Geng Y, Yu X (2013) A review of the circular economy in China: moving from rhetoric to implementation. J Clean Prod 42:215-227. https://doi.org/10.1016/j.jclepro.2012.11.020

Teece DJ, Pisano G, Shuen A (1997) Dynamic capabilities and strategic managemen. Strat Manag J 18(7): 509-533

Temesgen A, Storsletten V, Jakobsen O (2019) 'Circular economy - reducing symptoms or radical change?' Philos Manag (1). https://doi.org/10.1007/s40926-019-00112-1

Todeschini BV, Cortimiglia MN, Callegaro-de-Menezes D, Ghezzi A (2017) Innovative and sustainable business models in the fashion industry: entrepreneurial drivers, opportunities, and challenges. Bus Horiz 60(6):759-770. https://doi.org/10.1016/j.bushor.2017.07.003

Truffer B, Voß J-P, Konrad K (2008) Mapping expectations for system transformations. Technol Forecast Soc Chang 75(9):1360-1372. https://doi.org/10.1016/j.techfore.2008.04.001

Tukker A (2004) Eight types of product-service system: eight ways to sustainability? Experiences from suspronet. Bus Strateg Environ 13(4):246-260. https://doi.org/10.1002/bse.414

Tukker A (2015) Product services for a resource-efficient and circular economy - a review. J Clean Prod 97 : 76-91. https://doi.org/10.1016/j.jclepro.2013.11.049

Tukker A, Tischner U (2006) Product-services as a research field: past, present and future. Reflections from a decade of research. J Clean Prod 14(17):1552-1556. https://doi.org/10.1016/j.jclepro.2006.01.022 
Ünal, E., Urbinati, A., \& Chiaroni, D. (2018). Managerial practices for designing circular economy business models. Journal of Manufacturing Technology Management, JMTM-02-2018-0061. https://doi.org/10. 1108/JMTM-02-2018-0061

Valentinov V (2015) Kenneth boulding's theories of evolutionary economics and organizational change: a reconstruction. Journal of Economic Issues 49(1):71-88. https://doi.org/10.1080/00213624.2015. 1013880

Valkokari, K., \& Antikainen, M. (2016). A framework for sustainable circular business model innovation. Technol Innov Manag Rev, 5(7), 1-65. https://doi.org/http://timreview.ca/article/1000

van Buren N, Demmers M, van der Heijden R, Witlox F (2016) Towards a circular economy: the role of Dutch logistics industries and governments. Sustainability (Switzerland) 8(7):1-17. https://doi.org/10. 3390/su8070647

Vanegas P, Peeters JR, Cattrysse D, Tecchio P, Ardente F, Mathieux F et al (2018) Ease of disassembly of products to support circular economy strategies. Resour Conserv Recycl 135(January 2017):323-334. https://doi.org/10.1016/j.resconrec.2017.06.022

Vermunt DA, Negro SO, Verweij PA, Kuppens DV, Hekkert MP (2019) Exploring barriers to implementing different circular business models. J Clean Prod 222:891-902. https://doi.org/10.1016/j.jclepro.2019.03. 052

Ward B, Dubos R (1983) Only one earth. Norton, New York

Van Weelden E, Mugge R, Bakker C (2016) Paving the way towards circular consumption : exploring consumer acceptance of refurbished mobile phones in the Dutch market. J Clean Prod 113:743-754. https://doi.org/10.1016/j.jclepro.2015.11.065

WEF, Ellen MacArthur Foundation, \& McKinsey \& Company. (2014). Towards the Circular Economy : Accelerating the scale-up across global supply chains. World Economic Forum, (January), 1-64. https:// doi.org/10.1162/108819806775545321

Williamson J (1966) Profit, growth and sales maximization. Economica 33(129):1-16

Williamson O (1970) Corporate control and business behavior. Prentice-Hall, Englewood Cliff

Whalen KA, Milios L, Nussholz J (2018) Bridging the gap: barriers and potential for scaling reuse practices in the Swedish ICT sector. Resour Conserv Recycl 135(January 2017):123-131. https://doi.org/10.1016/j. resconrec.2017.07.029

Winans K, Kendall A, Deng H (2017) The history and current applications of the circular economy concept. Renew Sust Energ Rev 68(September 2016):825-833. https://doi.org/10.1016/j.rser.2016.09.123

Witjes S, Lozano R (2016) Towards a more circular economy: proposing a framework linking sustainable public procurement and sustainable business models. Resour Conserv Recycl 112:37-44. https://doi.org/ 10.1016/j.resconrec.2016.04.015

Xia, P., \& Yang, H. (2007). Re-reading steady-state economy: calm thinking on hot circular economy. Zhongguo Renkou Ziyuan Yu Huan Jing/ China Population Resources and Environment, 17(3), 2023..1016/S1872-583X(07)60012-6

Xu L, Zhang S, Yang M, Li W, Xu J (2018) Environmental effects of China's solar photovoltaic industry during 2011-2016: a life cycle assessment approach. J Clean Prod 170(2018):310-329. https://doi.org/10. 1016/j.jclepro.2017.09.129

Yong R (2007) The circular economy in China. Journal of Material Cycles and Waste Management 9(2):121129. https://doi.org/10.1007/s10163-007-0183-z

Zacho KO, Mosgaard M, Riisgaard H (2018) Capturing uncaptured values - a Danish case study on municipal preparation for reuse and recycling of waste. Resour Conserv Recycl 136(October 2017): 297-305. https://doi.org/10.1016/j.resconrec.2018.04.031

Zeng H, Chen X, Xiao X, Zhou Z (2017) Institutional pressures, sustainable supply chain management, and circular economy capability: empirical evidence from Chinese eco-industrial park firms. J Clean Prod 155(May 2014):54-65. https://doi.org/10.1016/j.jclepro.2016.10.093

Zheng, T., \& Chen, F. (2011). Analysis of technology innovation factors in circular economy system. https:// doi.org/10.1109/ICIII.2011.245

Zink T, Geyer R (2017) Circular economy rebound. J Ind Ecol 21(3):593-602. https://doi.org/10.1111/jiec. 12545

Publisher's note Springer Nature remains neutral with regard to jurisdictional claims in published maps and institutional affiliations. 